\title{
Plug-in Hybrid Ecological Category in Real Driving Emissions
}

\author{
Kinga Skobiej *(D) and Jacek Pielecha $(\mathbb{D}$ \\ Faculty of Civil and Transport Engineering, Poznan University of Technology, pl. M. Sklodowskiej-Curie 5, \\ 60-965 Poznan, Poland; jacek.pielecha@put.poznan.pl \\ * Correspondence: kinga.d.skobiej@doctorate.put.poznan.pl; Tel.: +48-61-665-2239
}

Citation: Skobiej, K.; Pielecha, J. Plug-in Hybrid Ecological Category in Real Driving Emissions. Energies 2021, 14, 2340. https://doi.org/ $10.3390 /$ en 14082340

Academic Editor: Constantine D. Rakopoulos

Received: 1 March 2021

Accepted: 17 April 2021

Published: 20 April 2021

Publisher's Note: MDPI stays neutral with regard to jurisdictional claims in published maps and institutional affiliations.

Copyright: (C) 2021 by the authors. Licensee MDPI, Basel, Switzerland. This article is an open access article distributed under the terms and conditions of the Creative Commons Attribution (CC BY) license (https:// creativecommons.org/licenses/by/ $4.0 /)$.

\begin{abstract}
Transportation, as one of the most growing industries, is problematic due to environmental pollution. A solution to reduce the environmental burden is stricter emission standards and homologation tests that correspond to the actual conditions of vehicle use. Another solution is the widespread introduction of hybrid vehicles-especially the plug-in type. Due to exhaust emission tests in RDE (real driving emissions) tests, it is possible to determine the real ecological aspects of these vehicles. The authors of this paper used RDE testing of the exhaust emissions of plug-in hybrid vehicles and on this basis evaluated various hybrid vehicles from an ecological point of view. An innovative solution proposed by the authors is to define classes of plug-in hybrid vehicles (classes from A to C) due to exhaust emissions. An innovative way is to determine the extreme results of exhaust gas emission within the range of acceptable scatter of the obtained results. By valuating vehicles, it will be possible in the future to determine the guidelines useful in designing more environmentally friendly power units in plug-in hybrid vehicles.
\end{abstract}

Keywords: exhaust emission; energy consumption; real driving emissions test

\section{Introduction}

The main problem of the ever-growing industry is its negative impact on the natural environment. One of the most dynamically changing sectors of industry is transport, which significantly contributes to air pollution. In order to reduce the impact of vehicles on the environment, increasingly stringent emission standards are introduced and solutions are sought that could allow minimization of the exhaust emissions from vehicles. One of the solutions proposed by the carmakers aiming at a global reduction of exhaust emissions is to replace as many conventional vehicles as possible with electric ones. Yet, due to the high cost of batteries, low vehicle range, and the lack of infrastructure, fully electric vehicles cannot fully replace the conventional ones. Manufacturers of conventional vehicles still struggle with the increasingly stringent exhaust emission standards.

The emission standards are set forth worldwide to control the pollutants emitted from vehicles to the atmosphere. The exhaust emissions are measured under the conditions of a predefined type of approval test. This part of the vehicle certification is responsible for its ecological properties and is the same for all passenger cars. The course of the test reflects the most probable road conditions and its performance, identical for all vehicles, entitles a comparison of the emission results among all the tested vehicles. These days, however, increased attention has been drawn to the performance of road tests, i.e., performed under actual traffic conditions. Currently, these tests are specified in the EU regulations as RDE (real driving emissions) [1-6]. They are carried out to most accurately reproduce the actual traffic conditions in the environmental aspect. Such tests must be performed in compliance with certain precisely defined requirements while at the same time allowing a relative arbitrariness, which significantly spreads the obtained exhaust emission results despite meeting the RDE requirements. The performed qualitative and quantitative analyses of the exhaust emissions in different tests was the subject of [7]. The authors proved that the values of relative road emissions depend more on the distance covered during the test than 
the duration of the test. The exhaust road emission values determined in different tests depend mainly on the type of test and are greater in shorter tests compared to the RDE test. The analysis of the investigations has confirmed that it is possible to shorten the tests by approximately $20 \%$ without a significant change in the exhaust emission results. This is confirmation of the increasing importance being placed on road test results, which must be verified for not only static parameters, but also, to a large extent, for dynamic parameters.

The detailed requirements of the RDE tests and the possibilities of optimization of a combustion engine were investigated by Pielecha and Skobiej [8]. The analysis of the emission level of individual exhaust components allowed the authors to show that the exhaust emission level may be lower by $26 \%$ to $81 \%$ compared to the road test performed under actual traffic conditions. The performed tests indicate that already at the stage of design, the engines can be optimized in terms of their exhaust emissions. Roadside emission tests have also been shown to be the most reliable vehicle performance information vehicle. The literature presented in this paper intends to indicate the actions and research aimed at increasing the environmental aspects of hybrid vehicles. These are both solutions involving better management of the energy stored in the batteries and technical solutions affecting the development of this type of vehicle.

A partial solution to the problem of the limited range of electric vehicles as well as its dependence on the traffic conditions is the introduction of a plug-in hybrid $[9,10]$. A plug-in hybrid combines the advantages of hybrid and electric vehicles. Compared to typical hybrids, the batteries used in plug-in hybrid electric vehicles (PHEVs) have greater capacity and range and can be charged from an external power supply. Such vehicles are more economical in terms of fuel consumption and more ecological in terms of exhaust emissions. Due to the fact that approximately 30-50 km [11] can be covered using electrical energy, PHEVs are more ecological than the conventional ones.

Cieslik et al. [12] investigated an electric vehicle under varied vehicle operating conditions, particularly the influence of the weather on the energy consumption by the vehicle. Under actual traffic conditions in sub-zero temperatures, the energy consumption in such a vehicle is greater by $14 \%$ compared to warm weather. Similar investigations were carried out by Yi et al. [13], indicating that energy consumption in the electric vehicle (EV) may vary drastically depending on the driving conditions, which is extremely impactful on the vehicle range.

Li et al. in [14], observing the growing popularity of electric and plug-in hybrid vehicles, proposed a methodology of assessment of the energy distribution within a vehicle. Plug-in hybrids allow charging of the batteries while driving, which reduces the demand for energy from the external sources.

Pielecha et al. [15] compared vehicles of different powertrains: conventional, plug-in hybrid, and electric, in tests under actual traffic conditions. They showed that the plug-in hybrid consumes $20 \%$ less energy than the conventional vehicle.

As per the IEA, the Global EV Outlook 2020 reported [16] that since 2010 (last 10 years), the number of electric vehicles has increased and today their share in the market amounts to $2.5 \%$ ( 1 in 40 new vehicles is fitted with an electric powertrain), including $74 \%$ fully electric ones and $26 \%$ plug-in hybrids. The increase in the number of plug-in hybrid vehicles is presented in Figure 1, where the 2010-2019 phase is compared. In 2012, when the sales of plug-in hybrids were initiated, already 100,000 vehicles were located in the US. In 2017, the number of these vehicles exceeded 1 million, for which the greatest share was in Europe. The sales of plug-in hybrid vehicles reached a level of 2.4 million worldwide in 2019 and the highest number of these vehicles was recorded in Europe. 


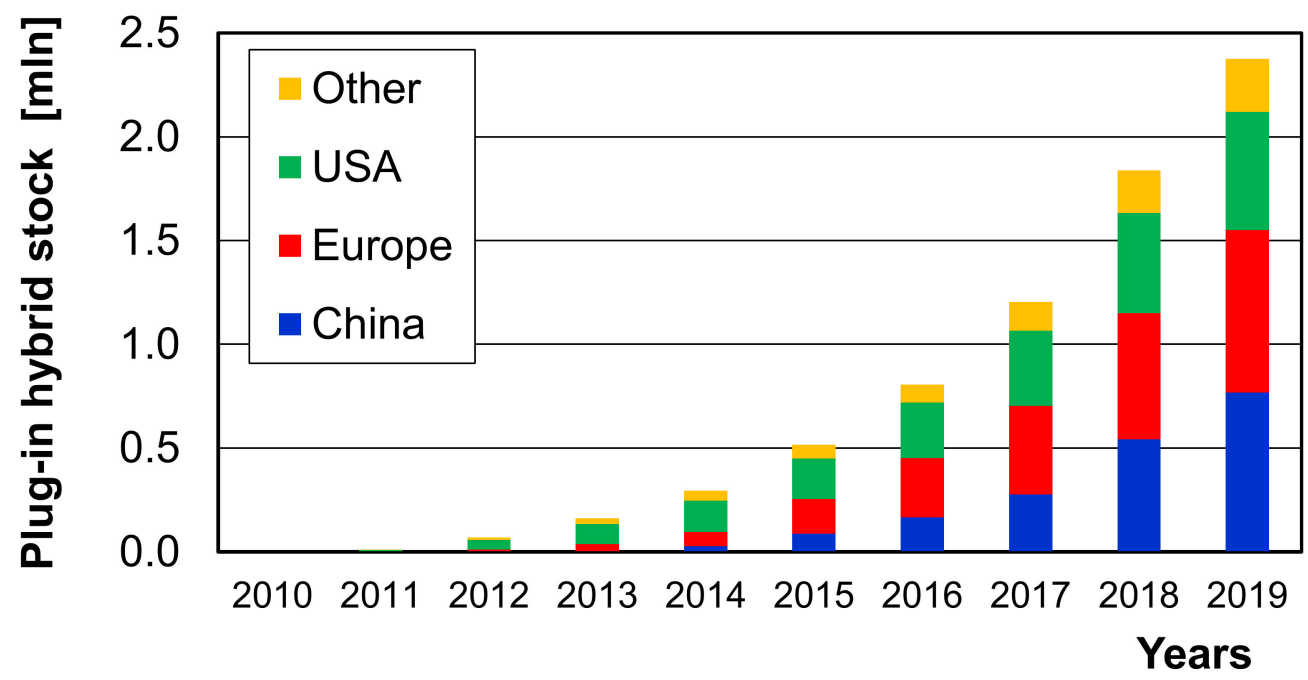

Figure 1. Increasing the number of plug-in hybrid vehicles between 2010 and 2019 globally (based on [16]).

Due to the fact that this type of vehicle is equipped with two sources of propulsion-a conventional internal combustion engine and an electric motor-it is necessary to optimally develop an energy management strategy and calibrate its parameters; the new system is designed to reduce emissions on the one hand and minimize energy consumption on the other.

\section{Aim of the Paper}

The addressing of the topic discussed in the paper is a result of social expectations, related to fair provision of vehicle emission-related information. Accusations were made that emission tests (particularly the type of approval tests) do not reflect the actual vehicle emissions, and, at the same time, the provided fuel economy information significantly diverges from the values obtained in daily vehicle operation. A similar topic, but in terms of a very broad scope of research, was addressed by the Initial Green Vehicle Index Roadmap project [17], where the assumption was to develop a basis for the comprehensive assessment of vehicles in terms of exhaust emissions, fuel consumption, and energy. The project, divided into phases between 2019 and 2030, assumed the study of exhaust emissions in type approval tests (NEDC, WLTC, and RDE) and, on this basis, the classification of vehicles on a 10-point scale of two indices: the clean air index and energy efficiency index. The clean air index compared on-road exhaust emissions with the permissible values-the lower the exhaust emissions, the higher the index value. The second index, the energy efficiency index, assessed the energy consumption of vehicles represented in $\mathrm{kWh} / 100 \mathrm{~km}$. Determination of the two indices and their respective values made it possible to assign a rating from 0 to 5 stars to the vehicle.

Therefore, the authors of this paper see the need for an objective approach to the assessment of the fuel consumption and exhaust emissions under actual operation of a vehicle. Such a particularization is necessary in the times of valuation of much data influencing, not only the vehicle operation, but also the choices of the end-users. A very good example is the valuation of the energy consumption of electric vehicles (though, conditioning of this parameter on external conditions should be required). The categorization of exhaust emission assessments conditional on the probability distribution of the results obtained in road tests is a novel approach. A novel method of determining the above will be the estimation of the extreme values of the exhaust emissions for a given vehicle within the admissible spreads of the road test results. Such a scenario, in the first stage, forced the application of a mathematical optimization apparatus in order to determine the minimum and the maximum values of the exhaust emissions and fuel consumption and, in the second stage, the need to practically validate the possibilities of obtaining such results 
from vehicles fitted with given powertrains (plug-in hybrid vehicles). The realization of such a research plan resulted in the development of a new tool that may be used in the environment-related assessment of motor vehicles under actual traffic conditions. In relation to this, the discipline of transport would gain another solution, serving the purpose of protecting the natural environment. Currently, the certificate of type approval provides the final values related to the conformity of a vehicle to a given ecological category without energy- and emission-related valuations in the said category. Currently, sold vehicles in the emission category of Euro 6 are not classified in terms of adequacy of the actual emission and fuel consumption with the values stated in the certificate of type approval. The aim of the paper is the development of a procedure, according to which one could assess whether the road emission test performed on a plug-in hybrid is reliable and, at the same time, indicate an interval of probability of meeting the requirements for tests carried out in the actual traffic. Such a task remains in line with the optimization tasks, in which one needs to determine the extreme values and indexes, to which the obtained emission result is to be compared. In the paper, the authors introduced valuation of vehicles in road tests (classes from A to C), which facilitates the assessment of the vehicle emission category of a PHEV (not only in the type approval but also in road exhaust emission tests).

The effect of the paper will be the possibility of assessing the adequacy of the exhaust emissions under actual traffic conditions based on the vehicle emission category and determining the index (valuation), directly translating the results of a type approval test to the road tests. By evaluating plug-in hybrids in environmental tests, it will potentially be possible not only to assess their actual environmental impact, but also to establish guidelines that will contribute to the design of more environmentally friendly powertrains in the future. The research presented in this paper is an alternative approach to the issues of environmental assessment of vehicles, although limiting oneself only to the emission of exhaust compounds-in the case of PHEVs-is not a complete solution. The next challenge, which is a continuation of the research, will be to develop a methodology for evaluating the energy consumption of such vehicles. The consequence of these actions will be the determination of the ecological assessment of conventional vehicles (evaluation of exhaust emissions), hybrid vehicles (evaluation of exhaust emissions and energy consumption), and electric vehicles (only energy consumption).

This procedure is motivated by the following reasons:

1. The proposal to categories vehicles was not developed on a large scale (with the exceptions quoted above), particularly in road emission tests. The projects so far have been mainly based on the exhaust emission results of homologation tests, in which the only criterion was the maximum value of exhaust emission. There is a research niche in the approach proposed in the paper-the authors propose two extreme values: maximum (used so far), but they also outline the methodology for determining the minimum value of exhaust emission.

2. The information defining the categorization of vehicles in road emissions tests in terms of, among other things, exhaust emissions reflects the latest literature data well:

- Electrified vehicles (ZEV and PHEV) will have a significantly large share (about $90 \%$ ) of the European market in 2030, of which more than $70 \%$ of such vehicles will be equipped with internal combustion engines [18].

- The environmental impact of hybrid combustion vehicles powered, e.g., by hydrogen is significantly lower than that of cars powered only with electric motors [19].

3. The proposal to categorize vehicles is not required by any legislation; however, the proposed method of exhaust emission assessment may be an indication of the direction of the development of regulations. Using the authors' methodology, the trend of evaluating the exhaust gas emission in the road tests could be maintained, e.g., with partial elimination of very complex type-approval tests. 
4. Increase public awareness of the environmental aspects of vehicles, which have a local and direct impact on human health (exhaust emissions), as opposed to energy consumption, which can be produced in a very distant area or from renewable sources.

\section{Methodology}

\subsection{Requirements for the Tests under Actual Traffic Conditions}

From 2017 onwards, the approval process for a new type of passenger car in the European Union includes a procedure for measuring emissions under real traffic conditions. The European Union Regulation (715/2007/EC [1] and 692/2008 [2]) on RDE tests is a response to the results of tests concerning the increased emission of nitrogen oxides from cars equipped with compression ignition engines, despite the fact that such vehicles met the acceptable standards in laboratory conditions. According to the RDE rules (Package 1-4), for all new approvals from September 2020, the emission of nitrogen oxides measured under road conditions will not exceed 1.43 times ( $\mathrm{CF}$ - conformity factors) the maximum limit (for Euro 6d-Temp is $60 \mathrm{mg} / \mathrm{km}$ ), i.e., $86 \mathrm{mg} / \mathrm{km}$ (Table 1). The parameters of the road tests are not arbitrary, and the moving average windows method (MAV) (also referred to in the literature as EMROAD, developed by the JRC) is used to determine emissions.

Table 1. Requirements for RDE testing in Europe [3-6].

\begin{tabular}{|c|c|c|c|c|c|c|c|}
\hline 2015 & 2016 & 2017 & 2018 & 2019 & 2020 & 2021 & 2022 \\
\hline \multicolumn{3}{|c|}{ Euro $6 \mathrm{~b}$} & \multicolumn{2}{|c|}{ Euro 6d-Temp } & \multicolumn{3}{|c|}{ Euro $6 \mathrm{~d}$} \\
\hline \multirow{2}{*}{\multicolumn{3}{|c|}{ NEDC }} & \multicolumn{5}{|c|}{ WLTC } \\
\hline & & & \multicolumn{5}{|c|}{ Conformity Factor (CF) } \\
\hline \multicolumn{3}{|c|}{ research and concept phase } & $\mathrm{CF}_{\mathrm{NOx}}=2.1$ & $\begin{array}{c}\mathrm{CF}_{\mathrm{NOx}}=1.5 \\
\mathrm{CF}_{\mathrm{PN}}=1.5\end{array}$ & \multicolumn{3}{|c|}{$\begin{aligned} \mathrm{CF}_{\mathrm{NOx}} & =1.43 \\
\mathrm{CF}_{\mathrm{PN}} & =1.5\end{aligned}$} \\
\hline
\end{tabular}

The route shall be chosen in such a way that the test is carried out without interruption, the data is recorded continuously, and the duration of the test is between 90 and $120 \mathrm{~min}$. The electrical energy for the PEMS (portable emission measurement system) shall be supplied by an external power supply and not by a source that draws its energy directly or indirectly from the engine of the vehicle under test. The installation of the PEMS system shall be carried out in such a way that it affects vehicle emissions, performance, or both as little as possible. Care shall be taken to minimize the mass of the installed equipment and potential aerodynamic changes in the test vehicle. RDE tests shall be conducted on working days, and on paved roads and streets (e.g., off-road driving is not permitted). Prolonged idling after the first ignition of the combustion engine at the start of the emission test shall be avoided (Table 2).

Table 2. Specific requirements of the RDE test [3-6].

\begin{tabular}{cc}
\hline Parameter & Requirement \\
\hline $\begin{array}{c}\text { ambient } \\
\text { temperature }\left(\mathrm{t}_{\mathrm{a}}\right)\end{array}$ & $\begin{array}{c}\text { normal range: } 0{ }^{\circ} \mathrm{C} \leq \mathrm{t}_{\mathrm{a}} \leq 30{ }^{\circ} \mathrm{C} \\
\text { lower extended range: }-7{ }^{\circ} \mathrm{C} \leq \mathrm{t}_{\mathrm{a}}<0{ }^{\circ} \mathrm{C} \\
\text { (emission corrective factor } 1 / 1.6)\end{array}$ \\
$\begin{array}{c}\text { upper extended range: } 30{ }^{\circ} \mathrm{C}<\mathrm{t}_{\mathrm{a}} \leq 35^{\circ} \mathrm{C} \\
\text { (emission corrective factor } 1 / 1.6)\end{array}$ \\
\hline $\begin{array}{c}\text { driving test } \\
\text { altitude }(\mathrm{h})\end{array}$ & $\begin{array}{c}\text { normal range: } \mathrm{h} \leq 700 \mathrm{~m} \text { a.s.l.; } \\
\text { extended range: } 700<\mathrm{h} \leq 1300 \mathrm{~m} \text { a.s.l. }\end{array}$ \\
\hline $\begin{array}{c}\text { impact evaluation of } \\
\text { ambient weather and } \\
\text { road conditions as well } \\
\text { as the driving style }\end{array}$ & $\begin{array}{c}\text { total altitude increase: less than } 1200 \mathrm{~m} / 100 \mathrm{~km} \text {; relative positive } \\
\text { product of velocity and acceleration }\left(\mathrm{V} \cdot \mathrm{a}_{+}\right): \text {less than } \mathrm{V} \cdot \mathrm{a}_{+} \text {max } \text { (for all } \\
\text { road conditions) }\end{array}$ \\
\hline
\end{tabular}


Table 2. Cont.

\begin{tabular}{|c|c|}
\hline Parameter & Requirement \\
\hline cold start & $\begin{array}{l}\text { duration of the cold start period is defined from engine start to first of } \\
5 \mathrm{~min} \text { or coolant temp } \geq 70{ }^{\circ} \mathrm{C} \text {; max velocity during cold start } \\
\leq 60 \mathrm{~km} / \mathrm{h} \text {; the average speed (including stops) shall be } \\
\text { between } 15 \mathrm{~km} / \mathrm{h} \text { and } 40 \mathrm{~km} / \mathrm{h} \text {; total stop time during cold start } \\
<90 \mathrm{~s} \text {; idling after ignition }<15 \mathrm{~s}\end{array}$ \\
\hline any vehicle stop & no longer than $180 \mathrm{~s}$ \\
\hline $\begin{array}{l}\text { vehicle aftertreatment } \\
\text { systems operation }\end{array}$ & $\begin{array}{l}\text { a single regeneration of the particulate filter justifies repeating the RDE } \\
\text { test; the occurrence of two filter regenerations is to be included in the } \\
\text { results of the RDE test }\end{array}$ \\
\hline $\begin{array}{l}\text { driving comfort } \\
\text { systems operation }\end{array}$ & $\begin{array}{l}\text { regular use as intended by the manufacturer (for example: use of the } \\
\text { air conditioning) }\end{array}$ \\
\hline vehicle load & $\begin{array}{l}\text { vehicle mass: driver (and passenger) along with the PEMS equipment; } \\
\text { maximum load }<90 \% \text { of the sum of the mass of the passengers and the } \\
\text { vehicle curb weight }\end{array}$ \\
\hline test requirements & duration $90 \mathrm{~min}-120 \mathrm{~min}$ \\
\hline $\begin{array}{l}\text { urban test phase } \\
\text { requirements }\end{array}$ & $\begin{array}{l}29-44 \% \text { share of the whole test time; distance: more than } 16 \mathrm{~km} \text {; vehicle } \\
\text { speed: up to } 60 \mathrm{~km} / \mathrm{h} \text {; average speed: } 15 \mathrm{~km} / \mathrm{h}-40 \mathrm{~km} / \mathrm{h} \text {; vehicle stop: } \\
\qquad 6-30 \% \text { of the urban phase of the test time }\end{array}$ \\
\hline $\begin{array}{l}\text { rural test phase } \\
\text { requirements }\end{array}$ & $\begin{array}{l}23-43 \% \text { share of the whole test time; distance: more than } 16 \mathrm{~km} \text {; vehicle } \\
\text { speed }(\mathrm{V}): 60 \mathrm{~km} / \mathrm{h}<\mathrm{V} \leq 90 \mathrm{~km} / \mathrm{h}\end{array}$ \\
\hline $\begin{array}{l}\text { motorway test phase } \\
\text { requirements }\end{array}$ & $\begin{array}{c}23-43 \% \text { share of the whole test time; distance: more than } 16 \mathrm{~km} \text {; vehicle } \\
\text { speed: more than } 90 \mathrm{~km} / \mathrm{h} \text {; vehicle speed over } 100 \mathrm{~km} / \mathrm{h} \text { for at least } \\
5 \mathrm{~min} \text {; vehicle speed over } 145 \mathrm{~km} / \mathrm{h} \text { no more than } 3 \% \text { of the test phase } \\
\text { time }\end{array}$ \\
\hline
\end{tabular}

\subsection{Research Equipment}

In order to measure the concentration of toxic compounds in the engine exhaust gas, mobile exhaust gas analyzers were used in stationary tests. The concentration of gaseous compounds was measured with the use of a Semtech DS analyser by Sensors. It enables measurement of the concentration of carbon monoxide, hydrocarbons, nitrogen oxides, and carbon dioxide, and, on the basis of oxygen concentration, the coefficient of excess air is determined.

The main purpose of the Semtech DS analyser is to measure the concentration of gaseous compounds from automotive vehicles. In this version, it can be used to test engines powered by different fuels, whose composition should be taken into account in the final data treatment (post processing). It is a representative of a group of PEMS-type measuring devices. It therefore meets the ISO 1065 standard for testing exhaust emissions with mobile systems. In addition to the possibility of using the analyser for in-service vehicle tests, it can be used as a measuring device for stationary tests, e.g., on an engine dynamometer. The Semtech DS analyser consists of the following measurement modules:

- Flame ionization detector (FID), which uses the change in electrical potential resulting from ionization of the particles in the flame; it is used to determine the total concentration of hydrocarbons;

- NDUV (non-dispersive ultra violet)-type analyser, using ultraviolet radiation to measure concentrations of nitrogen oxide and nitrogen dioxide;

- NDIR (non-dispersive infrared) analyser, using infrared radiation to measure concentrations of carbon monoxide and carbon dioxide;

- Electrochemical analyser to determine the oxygen concentration in the exhaust gas.

The Semtech DS analyser, in cooperation with a suitable flow meter, enables measurement of the exhaust mass flow rate. An important aspect is the appropriate thermal condition of the equipment, which is necessary to ensure stable indications. The time 
needed to obtain the appropriate temperature of the analyzer is $60 \mathrm{~min}$. The measurement starts with the introduction of the exhaust sample into the analyser through a measuring probe that maintains a temperature of $191^{\circ} \mathrm{C}$. The exhaust gas sample is then filtered from the particulate matter. The filtered sample is then subjected to a hydrocarbon concentration measurement. The next step is to cool the exhaust sample to $4^{\circ} \mathrm{C}$ and start measuring the concentration of nitrogen oxides, carbon monoxide, carbon dioxide, and oxygen. Table 3 presents the values of measurement uncertainty and the measurement range of particular modules of the Semtech DS analyser.

Table 3. Uncertainty of indications of individual measurement modules of the Semtech DS analyzer.

\begin{tabular}{|c|c|c|c|c|}
\hline Uncertainty & \multicolumn{2}{|c|}{ NDIR Analyser Indications } & \multicolumn{2}{|c|}{ NDUV Analyser Indications } \\
\hline Component & $\begin{array}{c}\text { Carbon } \\
\text { Monoxide }\end{array}$ & $\begin{array}{l}\text { Carbon } \\
\text { Dioxide }\end{array}$ & $\begin{array}{c}\text { Nitrogen } \\
\text { Oxide }\end{array}$ & $\begin{array}{c}\text { Nitrogen } \\
\text { Dioxide }\end{array}$ \\
\hline $\begin{array}{l}\text { measuring range } \\
\text { extended uncertainty } \\
\text { of measurement }\end{array}$ & $\begin{array}{c}0-8 \% \\
\pm 3 \% \text { reading } \\
\text { (or } 50 \text { ppm CO) }\end{array}$ & $\begin{array}{c}0-20 \% \\
\pm 3 \% \text { of reading } \\
\text { (or } 0.1 \% \mathrm{CO}_{2} \text { ) } \\
\text { whichever } \mathrm{i}\end{array}$ & $\begin{array}{l}0-2500 \mathrm{ppm} \\
\pm 3 \% \text { reading } \\
\text { (or } 15 \mathrm{ppm}) \\
\text { reater }\end{array}$ & $\begin{array}{l}0-500 \text { ppm } \\
\pm 3 \% \text { reading } \\
\text { (or } 10 \text { ppm) }\end{array}$ \\
\hline
\end{tabular}

For the measurement of particle diameters, a TSI Incorporated analyser-EEPS 3090 (Engine Exhaust Particle Sizer ${ }^{\mathrm{TM}}$ Spectrometer) was used. It allowed measurement of the discrete range of particle diameters (from $5.6 \mathrm{~nm}$ to $560 \mathrm{~nm}$ ) based on their different electrical mobility. Exhaust fumes are directed to the device through a dilution system and a system that maintains the required temperature. A pre-filter stops particles larger than $1 \mu \mathrm{m}$ in diameter that are outside the measuring range of the device. After passing through the neutralizer, the particles receive a positive electrical charge depending on their diameter. The particles deflected by the high-voltage inner electrode enter the ring slot. In the space between the inner electrode (having a positive electrical charge) and the outer cylinder (built as a stack of isolated electrodes arranged in rings), the electric charge of the collected particles (on the outer electrodes) is read by the processing system. Technical data of the TSI 3090 EEPS analyser are presented in Table 4.

Table 4. Spectrometer characteristics of EEPS TSI 3090.

\begin{tabular}{cc}
\hline Parameter & Value \\
\hline $\begin{array}{c}\text { range of measured particle diameters } \\
\text { measurement resolution (number of channels) } \\
\text { reading frequency } \\
\text { airflow }\end{array}$ & $\begin{array}{c}16 \text { channels per decade (total 32) } \\
\text { flue gas sample flow }\end{array}$ \\
$\begin{array}{c}\text { sample temperature range } \\
\text { operating temperature of the device } \\
\text { analyser weight }\end{array}$ & $40 \mathrm{dm}^{3} / \mathrm{min}$ \\
\end{tabular}

\subsection{Characteristics of the Research Objects}

The characteristic features of the research objects are presented in Table 5. All vehicles were plug-in hybrids. They varied in terms of the displacement of the fitted combustion engine, maximum power output, and torque. The vehicles were selected so as to most efficiently diversify and compare vehicles of different environmental performances. Vehicle $\mathrm{A}$ is characterized by the highest power output of the combustion engine and the electric motor and the highest battery capacity $(13.6 \mathrm{~kW} \cdot \mathrm{h})$. Vehicle B is distinguished by a continuously variable transmission, the lowest curb weight, and an average battery capacity $(8.8 \mathrm{~kW} \cdot \mathrm{h})$. Vehicle $\mathrm{C}$ is characterized by the highest engine capacity but has the lowest battery capacity $(3.3 \mathrm{~kW} \cdot \mathrm{h})$. Depending on the battery capacity, the vehicles were referred to as large battery (vehicle A), medium battery (vehicle B), and small battery (Vehicle C). 
Table 5. Technical parameters of plug-in vehicles.

\begin{tabular}{|c|c|c|c|}
\hline $\begin{array}{l}\text { Technical } \\
\text { Parameters }\end{array}$ & $\begin{array}{c}\text { Vehicle A } \\
\text { Large Battery }\end{array}$ & $\begin{array}{c}\text { Vehicle B } \\
\text { Medium Battery }\end{array}$ & $\begin{array}{c}\text { Vehicle C } \\
\text { Small Battery }\end{array}$ \\
\hline engine & gasoline, Turbo, R4 & gasoline, R4 & gasoline, R4 \\
\hline fuel system & direct injection & multipoint injection & direct injection \\
\hline engine displacement & $1395 \mathrm{~cm}^{3}$ & $1798 \mathrm{~cm}^{3}$ & $1999 \mathrm{~cm}^{3}$ \\
\hline max nower & $115 \mathrm{~kW}$ & $72 \mathrm{~kW}$ & $113 \mathrm{~kW}$ \\
\hline max. power & + 85 kW (electric) & + $53 \mathrm{~kW}$ (electric) & + $50 \mathrm{~kW}$ (electric) \\
\hline max. torque & $\begin{array}{c}250 \mathrm{Nm} / 1500-3500 \\
\mathrm{rpm} \\
+330 \mathrm{Nm} \text { (electric) }\end{array}$ & $\begin{array}{l}142 \mathrm{Nm} / 3600 \mathrm{rpm} \\
+163 \mathrm{Nm} \text { (electric) }\end{array}$ & $\begin{array}{l}189 \mathrm{Nm} / 5000 \mathrm{rpm} \\
+205 \mathrm{Nm} \text { (electric) }\end{array}$ \\
\hline gearbox & automatic, 6 gears & $\begin{array}{l}\text { automatic infinitely } \\
\text { variable e-CVT }\end{array}$ & automatic, 6 gears \\
\hline $\begin{array}{c}\text { size } \\
\text { (length/width/height) }\end{array}$ & $4869 / 1864 / 1503 \mathrm{~mm}$ & $4540 / 1760 / 1490 \mathrm{~mm}$ & $4855 / 1860 / 1470 \mathrm{~mm}$ \\
\hline curb weight & $1655 \mathrm{~kg}$ & $1375 \mathrm{~kg}$ & $1740 \mathrm{~kg}$ \\
\hline $\begin{array}{l}\text { average } \mathrm{CO}_{2} \\
\text { emissions }\end{array}$ & 31-42 g/km (WLTP) & 28-35g/km (WLTP) & $33 \mathrm{~g} / \mathrm{km}$ (WLTP) \\
\hline euro standard & Euro 6d-Temp & Euro 6-Temp & Euro 6 \\
\hline model year & 2020 & 2020 & 2019 \\
\hline battery & $13.6 \mathrm{~kW} \cdot \mathrm{h}$ & $8.8 \mathrm{~kW} \cdot \mathrm{h}$ & $3.3 \mathrm{~kW} \cdot \mathrm{h}$ \\
\hline
\end{tabular}

\subsection{Adopted Method to Search for the Function Minimum}

In search for the lowest road (specific) emission in the RDE test, a task was applied consisting in seeking the lowest value of the function of many variables while fulfilling the imposed conditions. Such a task was formulated in the form:

$$
\min \mathbf{f}(\mathbf{x})
$$

fulfilling the limitations:

$$
\begin{aligned}
& \mathbf{h}(\mathbf{x})=0, \\
& \mathbf{g}(\mathbf{x}) \leq 0
\end{aligned}
$$

where: $\mathbf{f}$-objective function of the optimization task, $\mathbf{h}(\mathbf{x})$ - equality limitations vector, and $\mathbf{g}(\mathbf{x})$-inequality limitation vector.

The above-presented general form of the objective function and the function of limitations requires an introduction of the modification of the objective function and limitations to enable an application of the general reduced gradient method. The general reduced gradient method belongs to a group of methods searching for the function minimums of many variables without limitations. The equality and inequality limitations can be considered by including them in the objective function:

$$
\mathrm{K}(\mathbf{x})=\mathrm{f}(\mathbf{x}) \sum_{\mathrm{i}} \mathrm{h}_{\mathrm{i}}^{2}(\mathbf{x})+1 /(2 \mu) \sum_{\mathrm{i}} \mathrm{W}(\mathbf{g})+1 /(2 \mu),
$$

where: $\mathrm{W}(\mathrm{g})=\mathrm{g}(\mathbf{x})-\mathrm{g}^{(\mathrm{min})}$ for $\mathrm{g} \leq \mathrm{g}^{(\mathrm{min})}$ and $\mu-$ par parameter modified in the optimization process.

The generalized reduced gradient (GNG) algorithm implemented in the Excel add-in Solver was used to perform the analysis. The principle of operation of the GNG algorithm in a shortened version is presented on the basis by Lasdon et al. [20]. Such an algorithm works very well for solving nonlinear problems; however, it is sensitive to the choice of initial data.

\section{Results}

\subsection{Validation of the Tests for Compliance with the Requirements}

In order to be able to compare the exhaust emissions in the first place, the nature of the test drives had to be compared. The performed tests were validated for their compliance 
with the RDE procedure, which requires three phases: urban, rural, and motorway. First, a formal check of the test drives was performed, and the detailed data are shown in Table A1 in Appendix A. All tests were repeated 5 times; tests in which extreme values were reached were rejected. For the purposes of this paper, the test that did not deviate by more than $10 \%$ from the average value in terms of the emissions of each exhaust constituent was assumed to be representative.

Despite meeting all the formal requirements for the tests, the most vital parameters were also compared that could have impact on the different emission results of the investigated vehicles. The course of the test route clearly indicates the three phases of the test (Figure 2a). We can distinguish the urban phase $20-25 \mathrm{~km}$, the rural phase-25 km to $50 \mathrm{~km}$, and the motorway phase- 60 to $90 \mathrm{~km}$. All three phases were rather similar in terms of their average speeds (Figure $2 b$ ). The spread of the average speed for the urban phase did not exceed $1 \mathrm{~km} / \mathrm{h}$; for the rural phase, $2 \mathrm{~km} / \mathrm{h}$; and for the motorway phase (the greatest), $5 \mathrm{~km} / \mathrm{h}$. The average value of the speed in the entire test was similar in each drive and amounted to 52,56 , and $54 \mathrm{~km} / \mathrm{h}$ for vehicles A, B, and C, respectively.

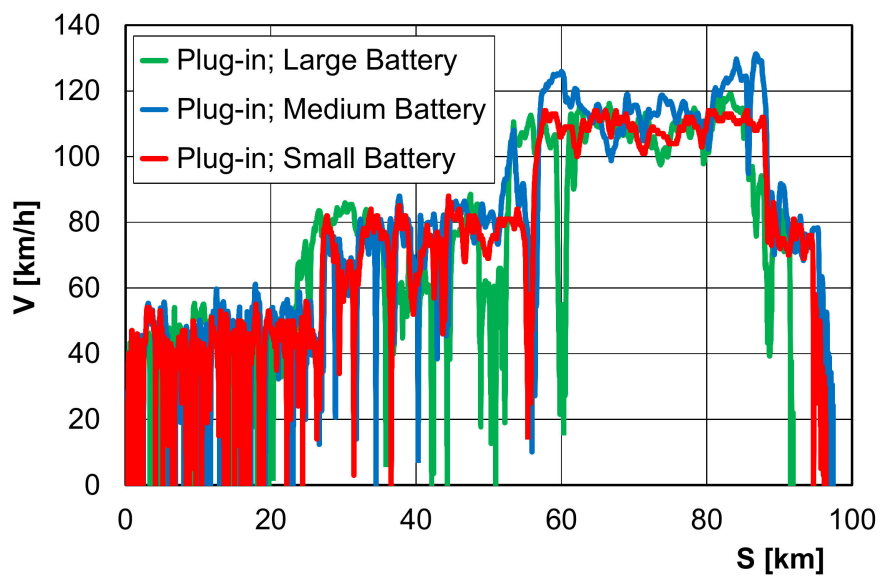

(a)

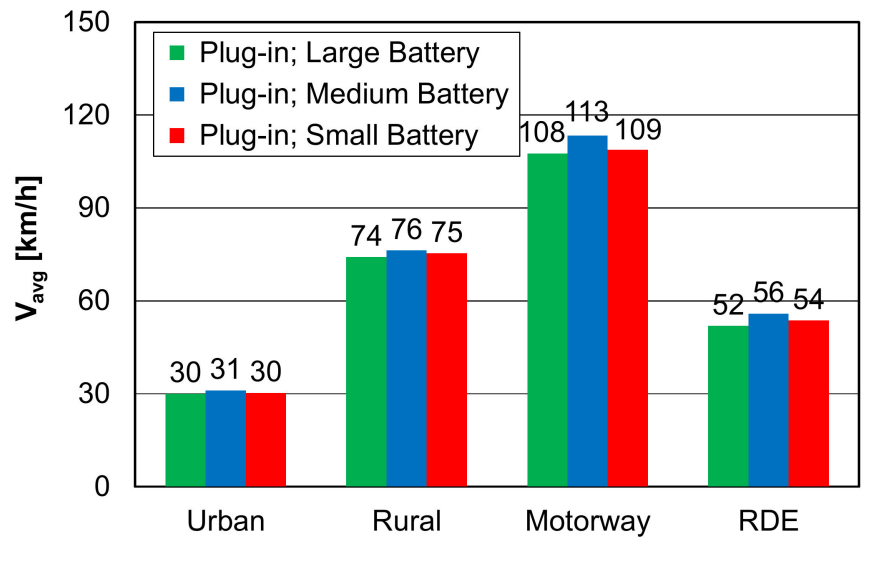

(b)

Figure 2. The tracings of the speed in the tests performed on the plug-in hybrids of different battery capacities (a) and average values of the speed in each phase of the test and in the entire RDE test (b).

In a second step, the authors compared the contribution of each phase of the RDE test for individual vehicles. The formal requirement is that the urban phase fills from $29 \%$ to $44 \%$, the rural phase $23 \%$ to $43 \%$, and the motorway phase $23 \%$ to $43 \%$ of the entire RDE test. The obtained results for the urban phase were $36.7 \%, 33.1 \%$, and $34.1 \%$ for vehicles A, B, and C, respectively (Figure 3). This means that the data variation described with the coefficient of variation $\mathrm{CoV}$ (the ratio of the standard deviation to the mean) is $1.5 \%$. This is a very small value and indicates a very high probability of the obtained results. For the rural phase of the test, the obtained results are $27.5 \%, 31.6 \%$, and $32.7 \%$, which gives a $\mathrm{CoV}=7.4 \%$. This value is several times higher than that from the urban phase. This phase of the test is characterized by a greater variability of vehicle speed and a greater share of unpredictable conditions. For the motorway phase, the shares in the entire test were $35.5 \%, 35.3 \%$, and $33.2 \%$, which gives a value of $\mathrm{CoV}=3.3 \%$. Such a comparison clearly confirms the similarity of the phase shares in the RDE test. It is noteworthy that, despite the allowable high variability in phase shares, the authors tried to keep the test drives very similar throughout the study, so that the emission results were only affected by traffic parameters (which the authors had no control over). 


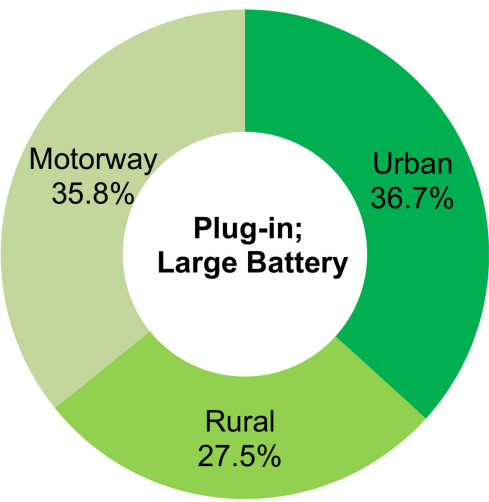

(a)

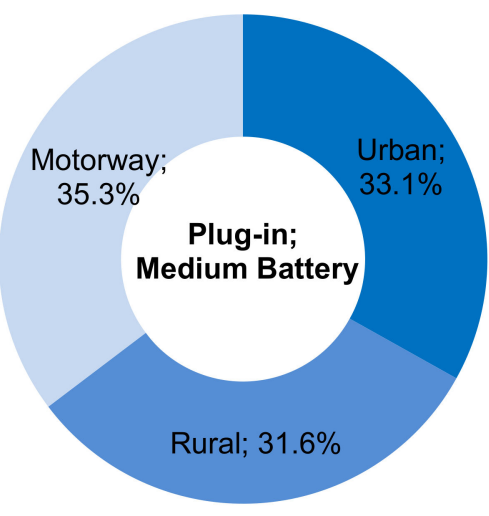

(b)

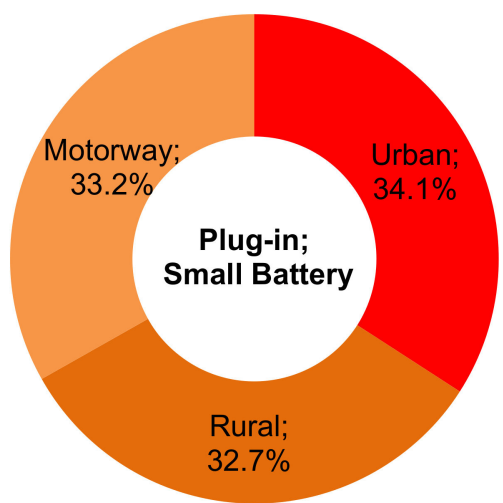

(c)

Figure 3. Comparison of the share of individual phases of the RDE test for the plug-in hybrids with a large (a), medium (b), and small (c) battery capacity.

The third and last stage of the comparison was determining the parameters characterizing the dynamic states of the vehicle operation. The first parameter was the $95 \%$ centile of the product of speed and positive acceleration (Figure $4 \mathrm{a}$ ), which, in each phase of the test, should be lower than the predefined maximum. The requirement is to make sure that the test drive is not excessively dynamic, and the vehicle accelerations do not drastically increase the dynamics, resulting in increased exhaust emissions. The values of this parameter for the urban part, shown in Figure $4 \mathrm{a}$, are in the range $9-12 \mathrm{~m}^{2} / \mathrm{s}^{3}$ and are similar for all test drives. For the rural phase, the obtained values of this parameter in individual drives have a greater spread $\left(14 \mathrm{~m}^{2} / \mathrm{s}^{3}\right.$ to $\left.18 \mathrm{~m}^{2} / \mathrm{s}^{3}\right)$. For the motorway phase, these values are the most similar and amount to approximately $14 \mathrm{~m}^{2} / \mathrm{s}^{3}$. It is noteworthy that in each phase of the test, the admissible value is not exceeded (marked with a continuous line). This suggests the correctness of the test realization in terms of driving dynamics. At the same time, it indicates a significant similarity, which will constitute a basis for the comparison of the exhaust emissions from the investigated vehicles.

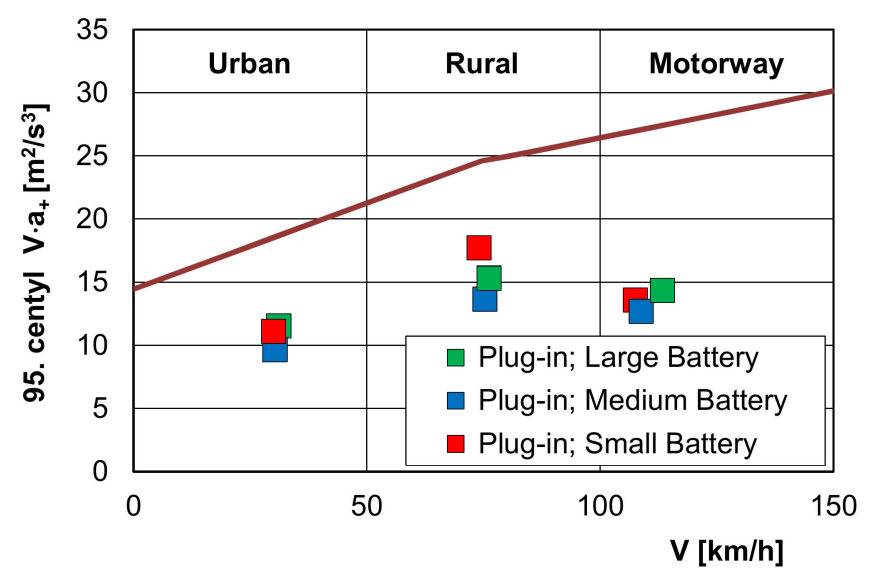

(a)

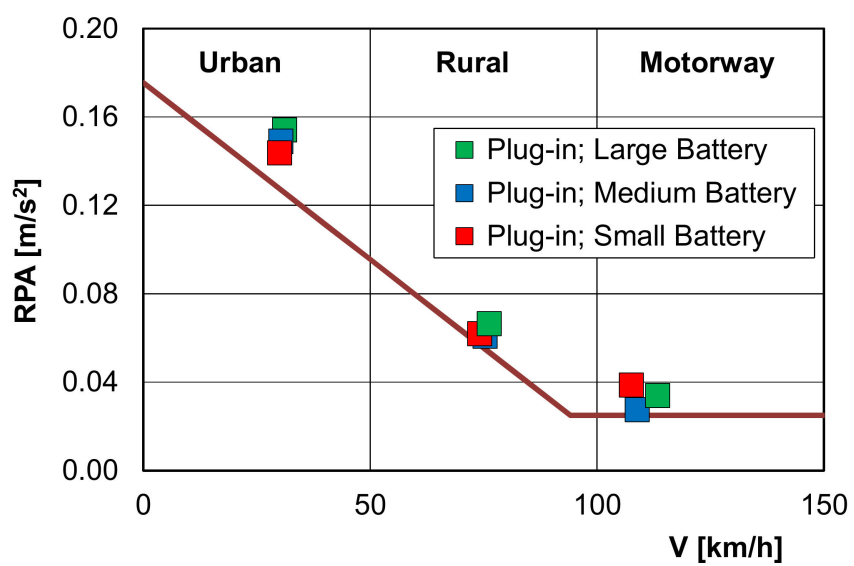

(b)

Figure 4. Comparison of the $95 \%$ centile of the product of vehicle speed and positive acceleration (a) and the relative positive acceleration $(\mathbf{b})$ in each phase of the test performed on the plug-in hybrids.

The other parameter describing the dynamic conditions was relative positive acceleration (Figure $4 \mathrm{~b}$ ). This parameter described the minimum dynamic conditions for the test drive not to be a steady state and to eliminate driving with the use of cruise control. Unfortunately, this parameter is determined on such a level that the performed tests are characterized by only slightly higher values than the minimum ones. For the urban part of 
the test, for all the vehicles, the relative positive acceleration fell in the range $0.14 \mathrm{~m} / \mathrm{s}^{2}$ to $0.16 \mathrm{~m} / \mathrm{s}^{2}$ and was approximately $10 \%$ greater than the minimum $\left(13 \mathrm{~m} / \mathrm{s}^{2}\right)$ defined for the obtained average speed in this phase (approximately $30 \mathrm{~km} / \mathrm{h}$ ). In the rural phase of the test, the values were even closer to one another, and fell in the range of approximately $0.6-0.7 \mathrm{~m} / \mathrm{s}^{2}$ and were greater than the minimum by approximately $5 \%$ (for the average speed of $75 \mathrm{~km} / \mathrm{h}$ ). In the motorway phase of the test, the relative positive acceleration was the lowest. It amounted to $0.3 \pm 0.04 \mathrm{~m} / \mathrm{s}^{2}$ and was slightly higher than the minimum defined on the level of $0.25 \mathrm{~m} / \mathrm{s}^{2}$.

The presented characteristics of the tests as well as the steady state and dynamic properties of the test drives prove that the formal requirements (presented in a concise form) for each of the test drives and each phase of the test were met. Such a situation implies the possibility of moving on to the next stage of the investigations, consisting in determining the exhaust emission values. Similar test conditions and similar dynamic parameters obtained for all the vehicles tested provide grounds for concluding that the exhaust gas emission results are not burdened with inaccuracy resulting from differences in the test course. At the same time, the similarity of the test runs indicate differences resulting only from individual vehicle characteristics, such as the engine used or battery capacity.

\subsection{Exhaust Emission Results}

Due to the fact that the engine was not in the initial phase of the RDE test, the characteristic aspect of the emission of individual exhaust components is the initial flat period of the relation. It results from the fact that the initial phase of the RDE test is performed only with the electric motor activated and the cold phase of the test is moved from the urban phase to the rural one (Figure 5a). This is particularly visible when we analyze the emission of carbon dioxide (shown in increments), from which we conclude that the vehicle of the lowest battery capacity drove approximately $40 \mathrm{~km}$ on the electric motor. The other vehicles used the electric motor for the distance of over $50 \mathrm{~km}$. The advantage of this situation is that the engine warm-up time is reduced. This is due to the fact that there is a higher engine speed and load during the rural phase of the test. This results in much faster catalytic converter firing and a reduced cold start time. The downside, however, is the fact that the cold engine operation at higher loads and speeds results in higher emissions of individual exhaust components. This is particularly visible in the analysis of the emission of carbon monoxide (Figure $5 b$ ), where the start of a cold engine (vehicle A) in a very short time resulted in emission of almost $50 \%$ of the entire emission of this component (approximately $30 \mathrm{mg} / \mathrm{km}$ for the distance of approximately $50 \mathrm{~km}$ and for the entire test this value was approximately $60 \mathrm{mg} / \mathrm{km}$ for the distance of approximately $100 \mathrm{~km}$ ).

A separate comment is required related to the nature of the changes in the emission of carbon monoxide for the medium-battery plug-in hybrid, for which this emission drops as the test continues (from $70 \mathrm{~km}$ onwards). This is caused by the lowest increment of the mass of carbon monoxide compared to the distance covered by the vehicle. In the outstanding two cases, the increase in the mass of carbon monoxide was greater than the increment in the covered distance. For each investigated vehicle, the emission of carbon monoxide was lower than the admissible one $(1000 \mathrm{mg} / \mathrm{km}$ Euro $6 \mathrm{~d}-\mathrm{Temp})$. For individual vehicles, the obtained values of the emission of this component, defined as the total mass of the emitted component against the total covered distance, are: 63, 74, and $109 \mathrm{mg} / \mathrm{km}$, for vehicle $\mathrm{C}, \mathrm{B}$, and $\mathrm{A}$, respectively. 


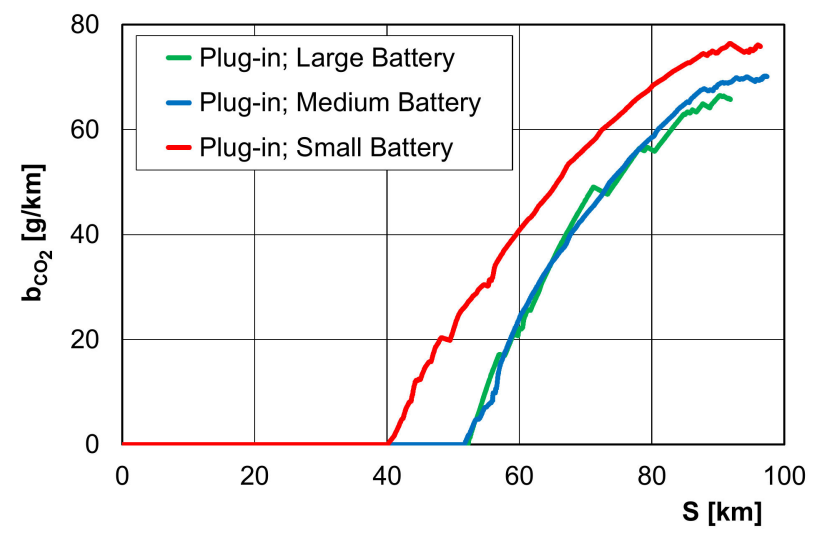

(a)

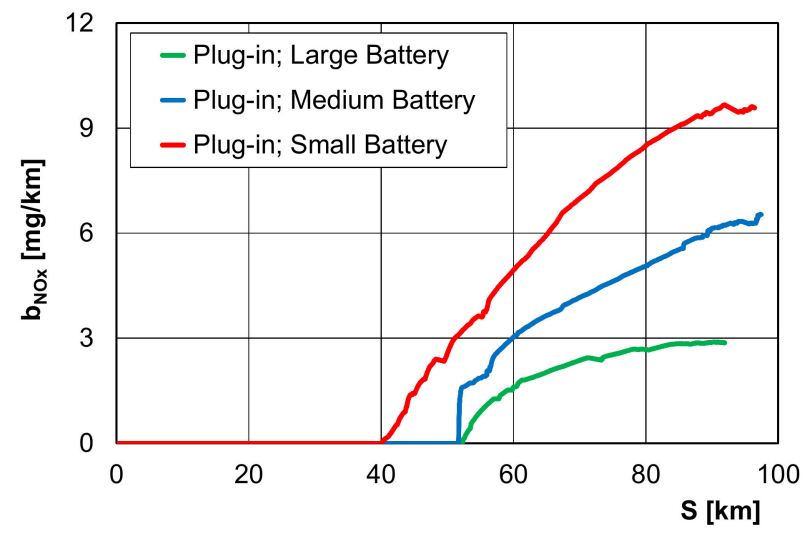

(c)

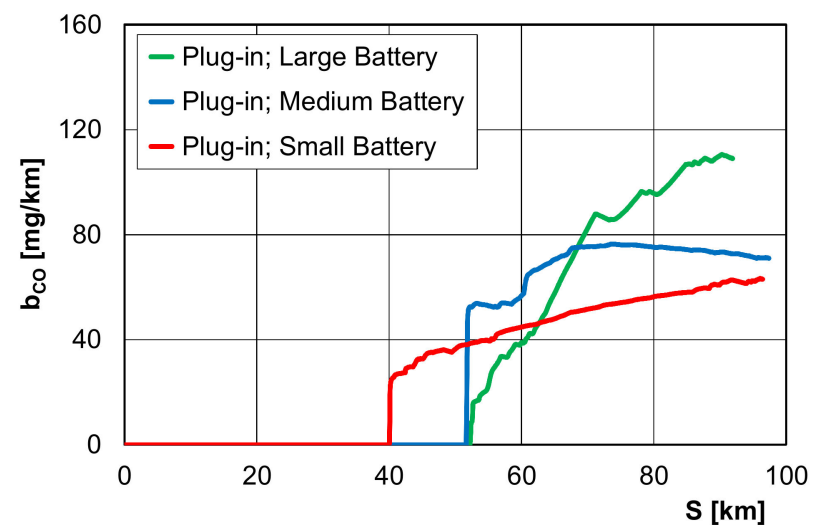

(b)

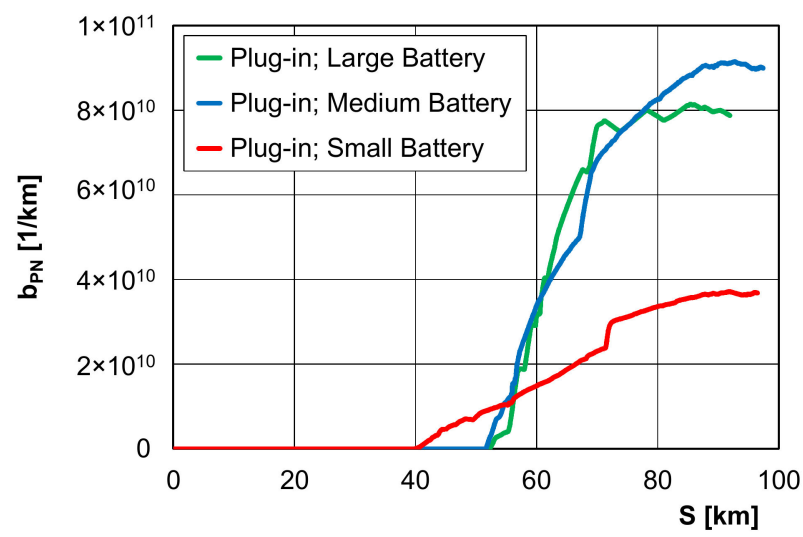

(d)

Figure 5. Dependence of the emission of carbon dioxide (a), carbon monoxide (b), nitrogen oxides (c), and particle number (d) on the distance covered during the road tests for individual investigated vehicles; the curves were made using the emission intensity results obtained in each second of the test.

The nature of the changes in the emission of nitrogen oxides (Figure 5c) was heavily dependent on the engine displacement and the vehicle weight. Vehicle $C$ (of the highest curb weight and engine displacement) was characterized by the highest emission of nitrogen oxides and, at the same time, had a constant growing trend in the rural and motorway cycles. The final value of the emission of nitrogen oxides obtained using all the data related to the emission intensity in the entire RDE test was $9.5 \mathrm{mg} / \mathrm{km}$, which is an approximately $50 \%$ higher value compared to vehicle $B(6.4 \mathrm{mg} / \mathrm{km})$ and more than 3 times higher than the results obtained for vehicle A (approximately $3 \mathrm{mg} / \mathrm{km}$ ). In the final described case, vehicle $A$ had the engine of the lowest displacement, but the engine was turbocharged. The catalytic converter significantly reduces the concentration of nitrogen oxides in the exhaust system, which is particularly visible in modern turbocharged engines. The obtained values of the emission of nitrogen oxides do not exceed the limits prescribed in the Euro 6d-Temp standard, which amounts to $60 \mathrm{mg} / \mathrm{km}$.

A different tracing from the previous one was obtained for particle number (Figure $5 d$ ). The smallest increase was observed for vehicle $C$, for which the greatest emission of nitrogen oxides was recorded, which confirms the inversely proportional relation between these exhaust components. When comparing the obtained results of all the investigated vehicles, we know that the particle number is lower than the prescribed limit, which amounts to $6 \cdot 10^{11} 1 / \mathrm{km}$ for the direct-injected engines. Determining the total exhaust emissions in the tests requires an application of an averaging algorithm of the emissions in the measurement windows that are determined based on the emission of carbon dioxide in individual phases of the WLTC test (red dots in Figure 5). 
The value of the road emission of carbon dioxide in the RDE test, determined individually for each of the vehicles, in the majority of cases falls between the lower $\left(\mathrm{Tol}_{\text {low }}=0\right)$ and the upper $\left(\mathrm{Tol}_{\text {high }}=+45 \%\right.$ ) limit of tolerance. In all the investigations of the plug-in hybrids, one can see a similarity of the distribution of the average emission of carbon dioxide in the measurement windows (Figure 6): for the speed in the range up to $75 \mathrm{~km} / \mathrm{h}$, the observed values do not exceed $100 \mathrm{~g} / \mathrm{km}$. In the range from $75 \mathrm{~km} / \mathrm{h}$ to $125 \mathrm{~km} / \mathrm{h}$, the emission values of carbon dioxide are from $100 \mathrm{~g} / \mathrm{km}$ to $200 \mathrm{~g} / \mathrm{km}$ for vehicle A (Figure 6a); for vehicle B, up to $220 \mathrm{~g} / \mathrm{km}$ (Figure 6b); and for vehicle C, up to $150 \mathrm{~g} / \mathrm{km}$ (Figure 6c).

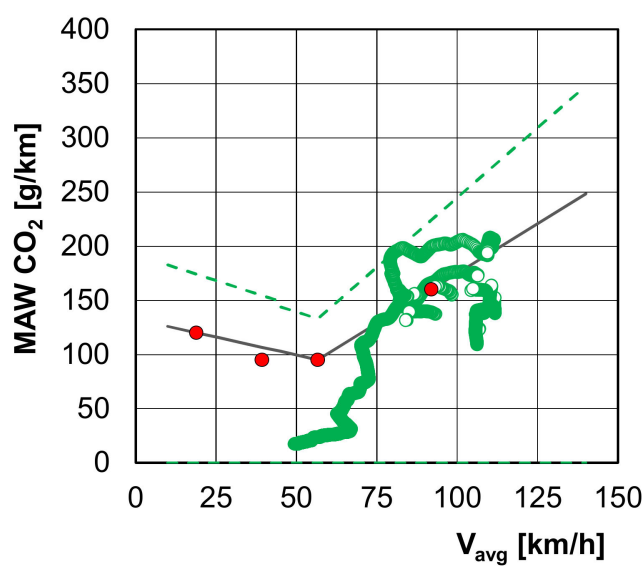

(a)

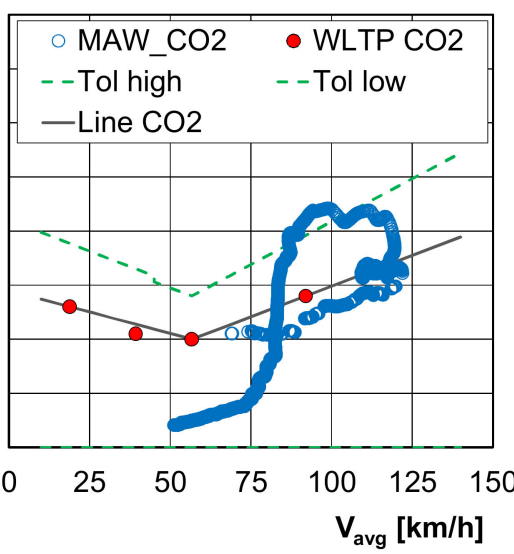

(b)

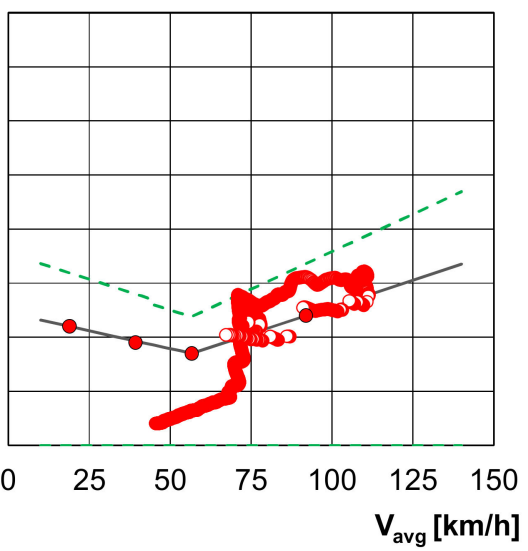

(c)

Figure 6. Characteristic curves determining the relation between the emissions of carbon dioxide in the measurement windows that are the basis for the determination of the emission of individual exhaust components in the RDE test for: Plug-in, Large Battery (a), Plug-in, Medium Battery (b), Plug-in, Small Battery (c).

Analyzing the carbon dioxide emissions for the different phases of the RDE test reveals zero emissions of this component in the urban phase for all plug-in hybrid vehicles tested (Figure 7a). The differences are visible only in the subsequent phases of the test: in the rural phase, the greatest emission occurs for the vehicle with the smallest battery capacity $(49 \mathrm{~g} / \mathrm{km})$ and the lowest emission occurs for vehicle B with the medium battery capacity $(32 \mathrm{~g} / \mathrm{km})$. The greatest values of the emission of carbon dioxide were recorded in the motorway phase of the test: 3-4 times higher compared to the rural phase. The greatest emission of carbon dioxide $(159 \mathrm{~g} / \mathrm{km})$ is for the vehicle with the lowest engine displacement, which suggests the load of the powertrain. At the same time, it is confirmation of the fact that downsized engines fitted in vehicles of relatively high curb weight do not ensure the expected environmental results. The final result of the road emission of carbon dioxide for all the vehicles is $63 \pm 2 \mathrm{~g} / \mathrm{km}$, which means that none of the values differed from one another by more than $3.2 \%$. This is a very similar result confirmed by the gas mileage of 2.6, 2.8, and $3.0 \mathrm{dm}^{3} / 100 \mathrm{~km}$ for vehicles A, B, and C, respectively. This is caused by the fact that the electric mode was used in each phase of the test by each vehicle and its share was $60 \%, 53 \%$, and $48 \%$ for vehicles $\mathrm{A}, \mathrm{B}$, and C, respectively. 


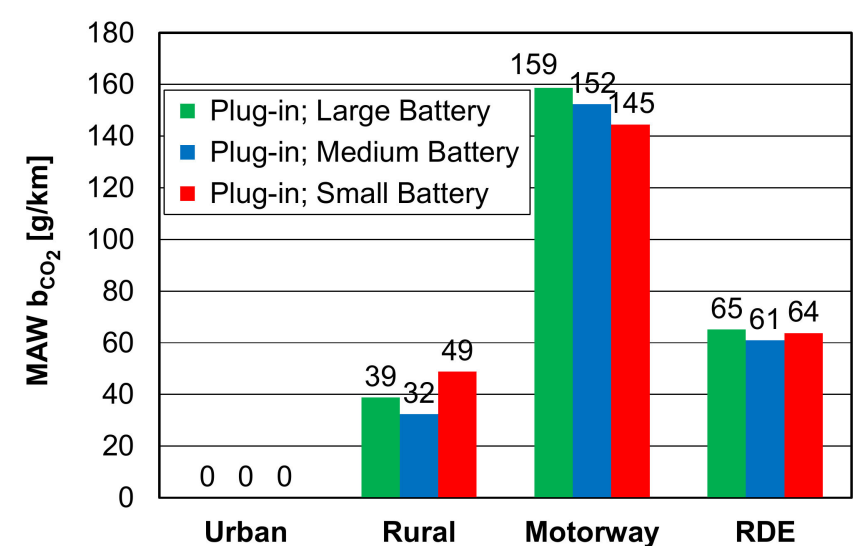

(a)

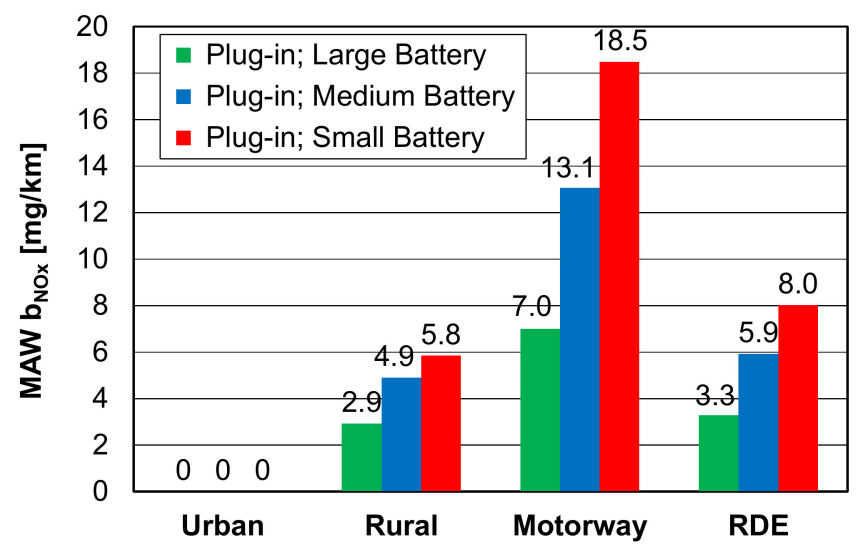

(c)

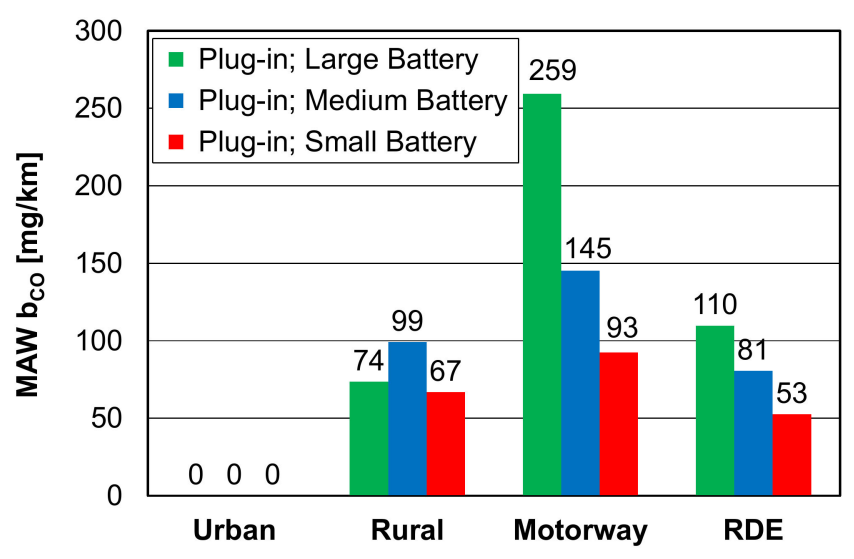

(b)

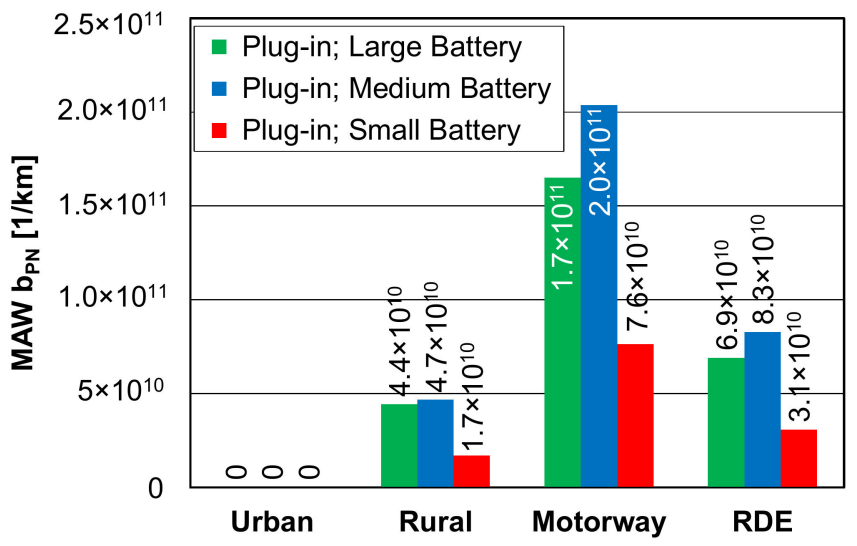

(d)

Figure 7. Road emission of carbon dioxide (a), carbon monoxide (b), nitrogen oxides (c), and particle number (d) for each phase of the test and in the entire RDE test for individual plug-in hybrid vehicles; the values were determined using an algorithm allowing for averaging in the measurement windows.

Much greater differences in individual phases of the test were recorded for the emission of carbon monoxide (Figure $7 \mathrm{~b}$ ). Similar to the previous case, the urban phase was characterized with zero emission of this component and in the rural phase, the differences were significant and amounted to $33 \%$ (for vehicle $\mathrm{B}$, the emission of this component was $99 \mathrm{mg} / \mathrm{km}$ and for vehicle C, $67 \mathrm{mg} / \mathrm{km}$ ). Vehicle A reached an intermediate value of $74 \mathrm{mg} / \mathrm{km}$. An even greater divergence was recorded in the motorway phase of the test, where, similar to carbon dioxide, the highest values $(259 \mathrm{mg} / \mathrm{km})$ were recorded for vehicle A (downsizing) and the smallest $(93 \mathrm{mg} / \mathrm{km}$ ) for vehicle $\mathrm{C}$ (the greatest displacement). This translated into the final values that, for vehicle $A(110 \mathrm{mg} / \mathrm{km})$, were twice as high compared to vehicle $C(53 \mathrm{mg} / \mathrm{km})$. It is noteworthy that these values are 10-20 times lower than the admissible ones prescribed in the Euro 6d-Temp standard, where the limit is $1000 \mathrm{mg} / \mathrm{km}$.

The road emission of nitrogen oxides was dependent on the engine displacement: the greater the engine displacement, the higher the emission of this component in individual phases of the RDE test (Figure 7c). The road emission of nitrogen oxides in the rural phase for all the tested vehicles was the result of the engine cold start in this phase. The recorded values of the road emission in the rural phase were $2.9 \mathrm{~g} / \mathrm{km}, 4.9 \mathrm{mg} / \mathrm{km}$, and $5.8 \mathrm{mg} / \mathrm{km}$ for vehicles A, B, and C, respectively. Vehicle $C$ generated twice the mass of nitrogen oxides compared to vehicle $\mathrm{A}$ (assuming the same distance in the rural phase of the test). The values of this parameter in the motorway phase were even more varied: vehicle $C$ 
generated 2.5 times the mass of nitrogen oxides compared to vehicle $\mathrm{A}$, which could have been caused by the mileage of this vehicle in the first place (MY 2019) and the reduced efficiency of the catalytic converter. The consequence is the final result of the emission of nitrogen oxides for vehicle $A$ of $3.3 \mathrm{mg} / \mathrm{km}$ and vehicle $C$ of twice as much $(8 \mathrm{mg} / \mathrm{km})$. These values are more than 10 times lower that the ones prescribed in the RDE standard: $60 \mathrm{mg} / \mathrm{km}\left(\mathrm{b}_{\mathrm{NOx}}\right.$ Euro 6d-Temp $) \times 1.43\left(\mathrm{CF}_{\mathrm{NOx}}\right)=86 \mathrm{mg} / \mathrm{km}$. The road emission of the particle number was quite the opposite compared to nitrogen oxides. The highest values in each phase of the test and in the entire RDE test were recorded for vehicle B (Figure 7d). These values were approximately $10-20 \%$ higher compared to vehicle $\mathrm{A}$, whose values were $0,4.4 \cdot 10^{10} 1 / \mathrm{km}, 1.7 \cdot 10^{11} 1 / \mathrm{km}$, and $6.9 \cdot 10^{10} 1 / \mathrm{km}$ in the urban, rural, motorway phase, and the entire test, respectively. The lowest emission of the particle number was vehicle $C$, for which the value in the entire RDE test was $3.1 \cdot 10^{10} 1 / \mathrm{km}$. All the obtained values were several times lower than the admissible limit of this component prescribed in the RDE test requirements, amounting to 1.5 times the limit of the Euro $6 \mathrm{~d}$-Temp standard $\left(6 \cdot 10^{10} 1 / \mathrm{km} \times 1.5=9 \cdot 10^{11} 1 / \mathrm{km}\right)$.

The above-presented procedure of determination of exhaust emissions under road conditions served to assess the environmental performance of three different plug-in hybrid vehicles. On this basis, the authors identified the exhaust emissions falling in the admissible limits, i.e., quantitative information was obtained. The qualitative information, however, was not assured, i.e., the result was not obtained against the environmental capabilities of a given plug-in hybrid vehicle model. The obtained results do not contain information on the scope of variability in the position of the results against the minimum and maximum obtainable values for each vehicle.

\section{Discussion}

The obtained on-road emission values from each vehicle were used as input parameters to determine the limits (where the values are possible). Specifying a maximum value is not questionable because it should be a limit:

$$
\mathrm{b}_{\mathrm{j}, \mathrm{max}}=\mathrm{b}_{\mathrm{j}, \text { Euro6d-Temp }} \times \mathrm{CF}_{\mathrm{j}}
$$

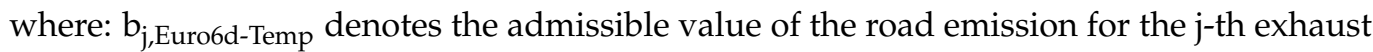
component $\left(\mathrm{b}_{\mathrm{CO} \text {,Euro 6d-Temp }}=1000 \mathrm{mg} / \mathrm{km}, \mathrm{b}_{\mathrm{NOx} \text {,Euro 6d-Temp }}=60 \mathrm{mg} / \mathrm{km}, \mathrm{b}_{\text {PN,Euro 6d-Temp }}\right.$ $=6 \cdot 10^{11} 1 / \mathrm{km}$ and $\mathrm{CF}_{\mathrm{j}}$ - conformity factor for the $\mathrm{j}$-th exhaust component $\left(\mathrm{CF}_{\mathrm{CO}}=2.1\right.$, $\left.\mathrm{CF}_{\mathrm{NOx}}=1.43, \mathrm{CF}_{\mathrm{PN}}=1.5\right)$.

The minimum values that vehicles can theoretically obtain were determined with constant and variable emission rates. Constant emissivity should be assumed when changes in emissivity do not appear in individual phases of the RDE test. This means that a significantly small standard deviation occurs from the average value described with the coefficient $\mathrm{CoV}<10 \%$. The exact values of $\mathrm{CoV}$ for the emission intensity of all the exhaust components from all the investigated vehicles are presented in Table 6.

Table 6. CoV coefficient for all the tested exhaust components.

\begin{tabular}{ccccccc}
\hline \multirow{2}{*}{ Exhaust Components } & \multicolumn{2}{c}{ Vehicle A } & \multicolumn{2}{c}{ Vehicle B } & \multicolumn{2}{c}{ Vehicle C } \\
& Rural & Motorway & Rural & Motorway & Rural & Motorway \\
\hline $\mathrm{CoV}_{\mathrm{CO} 2}[\%]$ & 93.9 & 21.7 & 78.3 & 28.4 & 125.4 & 14.6 \\
$\mathrm{CoV}_{\mathrm{CO}}[\%]$ & 86.0 & 33.5 & 77.5 & 61.0 & 552.0 & 17.5 \\
$\mathrm{CoV}_{\mathrm{NOx}}[\%]$ & 83.2 & 30.6 & 77.5 & 17.2 & 125.9 & 14.6 \\
$\mathrm{CoV}_{\mathrm{PN}}[\%]$ & 128.2 & 61.8 & 77.2 & 35.5 & 131.7 & 104.3 \\
\hline
\end{tabular}

It can be seen from Table 6 that all $\mathrm{CoV}$ values are greater than $10 \%$, so the emission intensity (or road emission value) must depend on a mean value that accurately describes the nature of changes in the said emission intensity (or road emission). In this paper, the 
minimum value of the exhaust emissions with both methods was determined irrespective of the above.

\subsection{Determining the Minimum Road Emissions}

\subsubsection{Constant Road Emission Intensity}

For the determination of the theoretical values of the minimum exhaust emissions, the authors used a method described in Section 3.4 of this paper. As the input values, the authors used the emission intensities of a given exhaust component $\mathrm{E}_{\mathrm{j}, \mathrm{k}}$, determined from the road emissions $b_{j, k} ; j=\mathrm{CO}_{2}, \mathrm{CO}, \mathrm{NO}_{\mathrm{x}}, \mathrm{PN}$, for the rural and motorway phases). In the urban phase, the emission intensity was 0 . The variable values of the algorithm were: urban, rural, and motorway test duration $\left(t_{k}\right)$ and the distance in the urban, rural, and motorway phases $\left(S_{k}\right)$. The limitations were:

- The sum of the entire test duration:

$$
\begin{gathered}
t_{U}+t_{R}+t_{M} \in(90-120 \mathrm{~min}) ; \\
S_{U} / t_{U} \in(15-40 \mathrm{~km} / \mathrm{h}) ; \\
\mathrm{S}_{\mathrm{R}} / \mathrm{t}_{\mathrm{R}} \in(40-80 \mathrm{~km} / \mathrm{h}) ;
\end{gathered}
$$

- Average speed in the urban phase

- Average speed in the rural phase

- Average speed in the motorway phase $S_{M} / t_{M} \in(80-140 \mathrm{~km} / \mathrm{h})$.

The initial values were: $t_{U}=t_{R}=t_{M}=30$ min and $S_{U}=S_{R}=S_{M}=16 \mathrm{~km}$.

The values of the emission intensity of individual exhaust components (Table 7) were obtained based on the average road emission, the time, and the distance covered in each test phase. The objective function had a form:

$$
b_{\mathrm{j}, \mathrm{RDE}}=0.34 \mathrm{~b}_{\mathrm{j}, \mathrm{U}}+0.33 \mathrm{~b}_{\mathrm{j}, \mathrm{R}}+0.33 \mathrm{~b}_{\mathrm{j}, \mathrm{M}}
$$

and upon including the constant emission intensity $E_{\mathrm{j}, \mathrm{k}}$ in each phase of the test:

$$
b_{j, R D E}=0.34 E_{j, U} t_{U} / S_{U}+0.33 E_{j, R} t_{R} / S_{R}+0.33 E_{j, M} t_{M} / S_{M} .
$$

Table 7. The value of the constant emission intensity for the phases of the RDE test (rural, motorway) as the algorithm input data.

\begin{tabular}{ccccccc}
\hline Emission & \multicolumn{2}{c}{ Vehicle A } & \multicolumn{2}{c}{ Vehicle B } & \multicolumn{2}{c}{ Vehicle C } \\
Intensity & Rural & Motorway & Rural & Motorway & Rural & Motorway \\
\hline $\mathrm{E}_{\mathrm{CO} 2}[\mathrm{~g} / \mathrm{s}]$ & 0.80 & 4.74 & 0.69 & 4.80 & 1.02 & 4.37 \\
$\mathrm{E}_{\mathrm{CO}}[\mathrm{mg} / \mathrm{s}]$ & 1.51 & 7.75 & 2.10 & 4.57 & 1.40 & 2.80 \\
$\mathrm{E}_{\mathrm{NOx}}[\mathrm{mg} / \mathrm{s}]$ & 0.06 & 0.21 & 0.10 & 0.41 & 0.12 & 0.56 \\
$\mathrm{E}_{\mathrm{PN}}[1 / \mathrm{s}]$ & $9.1 \cdot 10^{8}$ & $4.9 \cdot 10^{9}$ & $9.9 \cdot 10^{8}$ & $6.4 \cdot 10^{9}$ & $3.6 \cdot 10^{8}$ & $2.3 \cdot 10^{9}$ \\
\hline
\end{tabular}

Using the Solver tool (Excel MS Office ${ }^{\mathrm{TM}}$ ), for each of the vehicles, the duration of each of the test phases $\left(t_{k}\right)$, the distance covered in each of the test phases $\left(S_{k}\right)$, and the share of each test phase in the entire RDE test $\left(u_{k}\right)$ were determined. Detailed data are presented in Tables A2-A4 (Appendix A), for vehicles A-C, respectively. From the comparison of the data in the tables, the theoretical minimum value of the exhaust emissions is greater than zero, which means that the plug-in hybrid vehicle in the RDE test will always use a combustion engine. For vehicle $\mathrm{A}$, the minimum value of the road emission of carbon dioxide was $49 \mathrm{~g} / \mathrm{km}$; for carbon monoxide, $83 \mathrm{mg} / \mathrm{km}$; for nitrogen oxides, $2.5 \mathrm{mg} / \mathrm{km}$; and for the particle number, $5.2 \cdot 10^{10} 1 / \mathrm{km}$. It should be noted that the obtained values of the parameters of time $\left(t_{k}\right)$, test phase duration $\left(S_{k}\right)$, and test phase share $\left(u_{k}\right)$ were different for each exhaust component and the scatter of results in individual analyzed categories, as measured with the $\mathrm{CoV}$ coefficient, fell in the range from $1.1 \%$ to $5.7 \%$ (Table A2). For vehicle $B$, the following road emission values were obtained using the same pattern: $b_{\mathrm{CO} 2}$ $=48 \mathrm{~g} / \mathrm{km}, \mathrm{b}_{\mathrm{CO}}=65 \mathrm{mg} / \mathrm{km}, \mathrm{b}_{\mathrm{NOx}}=4.7 \mathrm{mg} / \mathrm{km}, \mathrm{a} \mathrm{b}_{\mathrm{PN}}=6.6 \cdot 10^{10} 1 / \mathrm{km}$, at the coefficient of variation $\mathrm{CoV}$ changing from $0.9 \%$ to $20 \%$ (Table A3). For vehicle $\mathrm{C}$, the values of individual parameters were as follows: $b_{\mathrm{CO} 2}=49 \mathrm{~g} / \mathrm{km}, \mathrm{b}_{\mathrm{CO}}=41 \mathrm{mg} / \mathrm{km}, \mathrm{b}_{\mathrm{NOx}}=6.2$ 
$\mathrm{mg} / \mathrm{km}, \mathrm{a} \mathrm{b}_{\mathrm{PN}}=2.4 \cdot 10^{10} 1 / \mathrm{km}$, at the coefficient of variation $\mathrm{CoV}$ changing from $0.0 \%$ do $12.4 \%$ (Table A4).

The obtained average values for individual vehicles and each exhaust component are shown in Figure 8. From this figure, the road emission of carbon dioxide for each vehicle falls in the range $60-80 \mathrm{~g} / \mathrm{km}$ (Figure $7 \mathrm{a}$ ) at the minimum value of approximately $49 \mathrm{~g} / \mathrm{km}$ (Figure 8a). The value was adopted obligatorily on the level of $95 \mathrm{~g} / \mathrm{km}$ (this is a target value for a manufacturer's vehicle fleet; however, this value may decrease in future years). The road emission of carbon monoxide for all the investigated vehicles was in the range $50-110 \mathrm{mg} / \mathrm{km}$ (Figure $7 \mathrm{~b}$ ) at the maximum value of $2100 \mathrm{mg} / \mathrm{km}$ and the minimum one of $40-80 \mathrm{mg} / \mathrm{km}$ (Figure $8 \mathrm{a}$ ). The road emission of nitrogen oxides fell in the range $3.3 \mathrm{mg} / \mathrm{km}-8.0 \mathrm{mg} / \mathrm{km}$ (Figure $7 \mathrm{c}$ ) at the maximum value of $86 \mathrm{mg} / \mathrm{km}$, determined according to Equation (5).

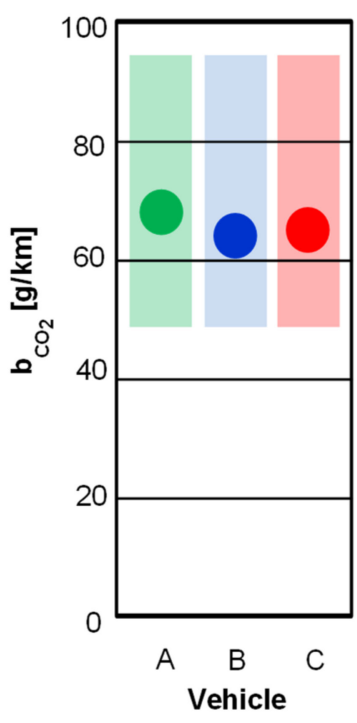

(a)

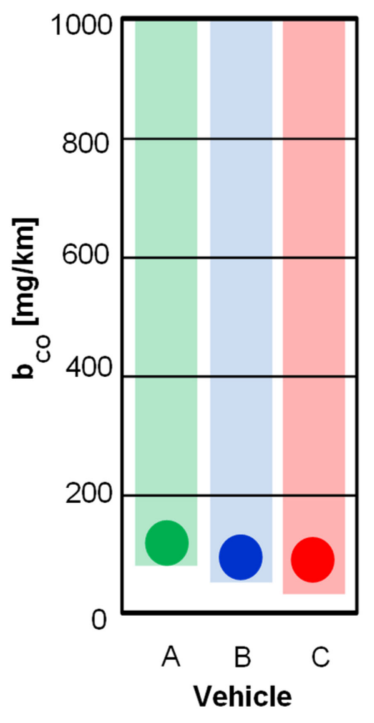

(b)

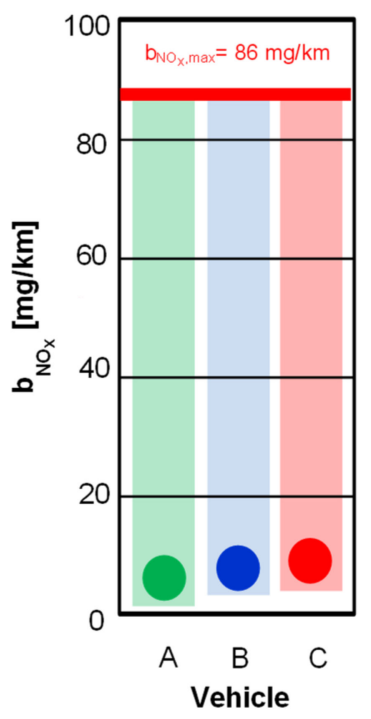

(c)

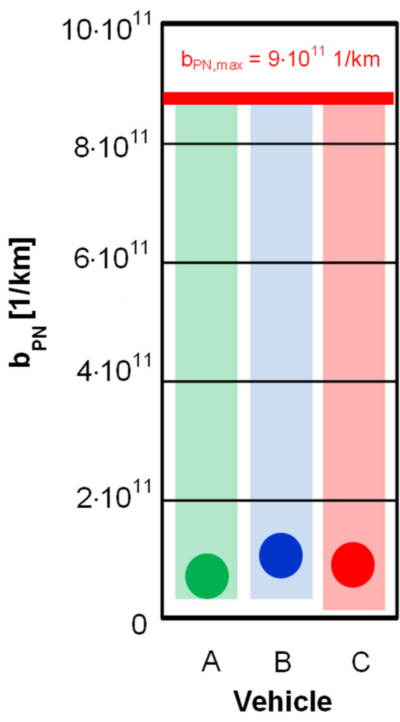

(d)

Figure 8. Values of the minimum road emission intensity of carbon dioxide (a), carbon monoxide (b), nitrogen oxides (c), and particle number $(\mathbf{d})$ in the RDE test obtained according to the algorithm for a constant emission intensity; data provided in Tables A2-A4.

The theoretical minimum value of the road emission of nitrogen oxides was in the range from $2.5 \mathrm{mg} / \mathrm{km}$ to $4.7 \mathrm{mg} / \mathrm{km}$ (Figure $8 \mathrm{c}$ ). The last investigated exhaust component, the road emission of particle number, was in the range from $3.1 \cdot 10^{10} 1 / \mathrm{km}$ to $8.3 \cdot 10^{10} 1 / \mathrm{km}$ (Figure 7d). For this parameter, the maximum value determined in Equation (5) is $9 \cdot 10^{11}$ $1 / \mathrm{km}$ and the minimum determined value falls in the range from $2.4 \cdot 10^{10} 1 / \mathrm{km}$ to $6.6 \cdot 10^{10}$ $1 / \mathrm{km}$ (Figure $8 \mathrm{~d}$ ).

\subsubsection{Variable Road Emission Intensity}

The determination of the minimum road emission using constant emission intensity of a given exhaust component does have its flaws: the engine warm up and increased catalyst efficiency after light-off are not allowed for. A more generalized approach may also be the use of the mathematical description of the curves presented in Figure 5, in relation to which the general form of Equation (2) assumes a form where individual values of the road emission for each exhaust component and each test phase will be dependent on the distance covered by the vehicle:

$$
\mathrm{b}_{\mathrm{j}, R D E}=0.34 \mathrm{~b}_{\mathrm{j}, \mathrm{U}}(\mathrm{S})+0.33 \mathrm{~b}_{\mathrm{j}, \mathrm{R}}(\mathrm{S})+0.33 \mathrm{~b}_{\mathrm{j}, \mathrm{M}}(\mathrm{S}) .
$$

In this case, we need to apply the non-continuous function for each exhaust component that will allow for the operation of the electric motor (in the range $S_{k} \leq S_{E V}$ ) during the 
urban and (partially) rural phases. For the outstanding distance, each course of the road emissions was described with a square Equation (9):

$$
b_{j, k}\left(S_{k}\right)= \begin{cases}0 & \text { for } S_{k} \leq S_{E V} \\ x_{j, k}\left(S_{k}\right)^{2}+y_{j, k} S_{k}+z_{j, k} & \text { for } S_{k}>S_{E V}\end{cases}
$$

where: $\mathrm{j}=\mathrm{CO}_{2}, \mathrm{CO}, \mathrm{NO}_{\mathrm{x}}, \mathrm{PN} ; \mathrm{S}$-distance $[\mathrm{km}] ; \mathrm{S}_{\mathrm{EV}}$-distance covered by the vehicle using an electric motor $[\mathrm{km}] ; \mathrm{k}=$ Vehicle $A$, Vehicle $B$, Vehicle $C$; and $\mathrm{x}_{\mathrm{j}, \mathrm{k}}, \mathrm{y}_{\mathrm{j}, \mathrm{k}}, \mathrm{z}_{\mathrm{j}, \mathrm{k}}$-multinomial coefficients (Table 8).

Table 8. Values of the equation indexes of the $\mathrm{z}, \mathrm{y}, \mathrm{z}$ multinomial and the coefficient of determination $\left(\mathrm{R}^{2}\right)$ for the road emission in the RDE test for each plug-in hybrid vehicle.

\begin{tabular}{|c|c|c|c|c|}
\hline $\mathbf{j}$ & $\mathbf{k}$ & Vehicle A & Vehicle B & Vehicle C \\
\hline \multicolumn{2}{|c|}{$\mathrm{S}_{\mathrm{EV}}[\mathrm{km}]$} & 52.2 & 51.6 & 40.0 \\
\hline \multirow{4}{*}{$\mathrm{b}_{\mathrm{CO} 2}[\mathrm{~g} / \mathrm{km}]$} & $x$ & -0.0351 & -0.0332 & -0.0201 \\
\hline & $\mathrm{y}$ & 6.6697 & 6.5103 & 4.1145 \\
\hline & $\mathrm{z}$ & -250.92 & -248.93 & -132.92 \\
\hline & $\mathrm{R}^{2}$ & 0.996 & 0.998 & 0.998 \\
\hline \multirow{4}{*}{$\mathrm{b}_{\mathrm{CO}}[\mathrm{mg} / \mathrm{km}]$} & $x$ & -0.0579 & -0.0322 & -0.0067 \\
\hline & $\mathrm{y}$ & 10.922 & 5.2708 & 1.5469 \\
\hline & $\mathrm{z}$ & -404.81 & -138.60 & -24.207 \\
\hline & $\mathrm{R}^{2}$ & 0.990 & 0.919 & 0.995 \\
\hline \multirow{4}{*}{$\mathrm{b}_{\mathrm{NOx}}[\mathrm{mg} / \mathrm{km}]$} & $x$ & -0.0024 & -0.0013 & -0.0021 \\
\hline & $\mathrm{y}$ & 0.4972 & 0.2977 & 0.3557 \\
\hline & $\mathrm{z}$ & -16.292 & -10.467 & -12.417 \\
\hline & $\mathrm{R}^{2}$ & 0.976 & 0.994 & 0.998 \\
\hline \multirow{4}{*}{$\mathrm{b}_{\mathrm{PN}}[1 / \mathrm{km}]$} & $x$ & $-5.91 \cdot 10^{7}$ & $-9.62 \cdot 10^{7}$ & $-6.33 \cdot 10^{6}$ \\
\hline & $\mathrm{y}$ & $1.08 \cdot 10^{10}$ & $1.59 \cdot 10^{10}$ & $1.58 \cdot 10^{9}$ \\
\hline & $\mathrm{z}$ & $-4.05 \cdot 10^{11}$ & $-5.76 \cdot 10^{11}$ & $-5.51 \cdot 10^{10}$ \\
\hline & $\mathrm{R}^{2}$ & 0.983 & 0.996 & 0.979 \\
\hline
\end{tabular}

The values of the multinomial coefficients $\left(x_{j, k}, y_{j, k}, z_{j, k}\right)$ are presented in Table 8 and their analysis indicates an increase in the road emissions upon exceeding the distance $\left(\mathrm{S}_{\mathrm{k}}>\right.$ $\mathrm{S}_{\mathrm{EV}}$ ), which is indicated by the negative value of each coefficient $x_{j, k}$.

The positive value of coefficient $y_{j, k}$ indicates a shift of the course of the emissions to the right for the increasing distance from the start of the test and the negative value of coefficient $z_{j, k}$ confirms the assumptions of zero emission of each exhaust component during the operation of the electric motor. In Table 8, the authors also provide the coefficient of determination $\left(\mathrm{R}^{2}\right)$, which indicates a very good fit of the adopted equation to the curves, showing the road emission of each exhaust component in the RDE test.

Utilizing Equation (9) and the data contained in Table 8, the minimum road emission of each of the exhaust components was determined in individual phases of the RDE test and in the entire test. The obtained detailed results regarding the duration of each phase of the test, the distance in each phase of the tests, and the share of each phase in the test are shown in Tables A5-A7 (Appendix A). The graphical presentation of the final relations is shown in Figure 9. From the figure, it is found that the minimum value of carbon dioxide for vehicles $A$ and $B$ is $0 \mathrm{~g} / \mathrm{km}$, which leads to the conclusion that the vehicle can cover the entire RDE test distance using an electric motor exclusively (which is compliant with the test detailed requirements). This is possible because the range of vehicles $\mathrm{A}$ and $\mathrm{B}$ on an electric motor was approximately $52 \mathrm{~km}$ and the minimum distance of the RDE test is 48 $\mathrm{km}$. Due to the fact that the combustion engine was off, the emission of the outstanding exhaust components from vehicles A and B was also zero. Only in the case of vehicle C with the small battery capacity was it impossible to carry out the entire RDE test exclusively 
using the electric motor. For this particular vehicle, the theoretical minimum values of the road emission are greater than zero for each of the exhaust components. However, when comparing the results obtained for constant and variable emission intensity, one can observe lower values for the latter method. It is probable that the theoretical minimum values of the road emission obtained using the variable emission intensity method during the road tests are closer to reality, which is why the authors recommend them for application in further research.

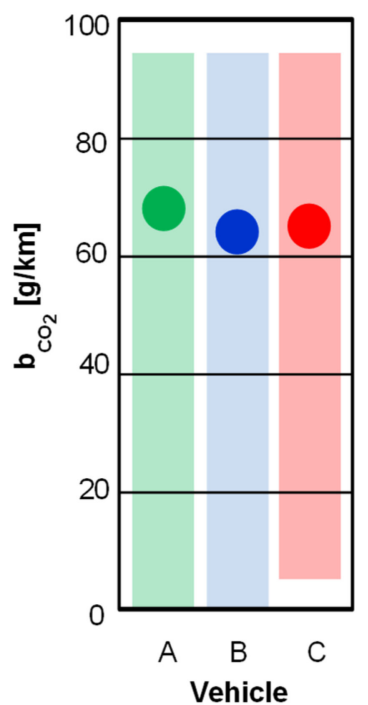

(a)

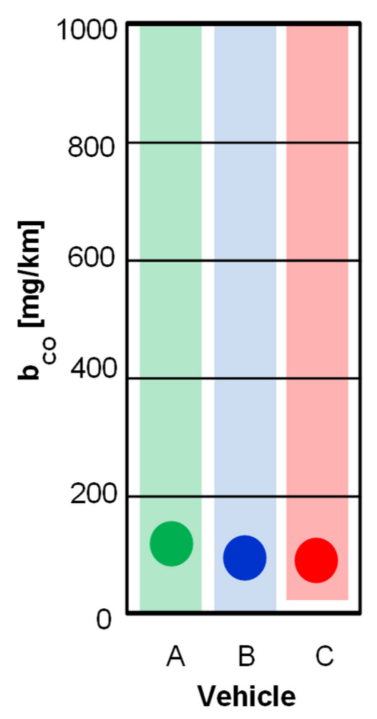

(b)

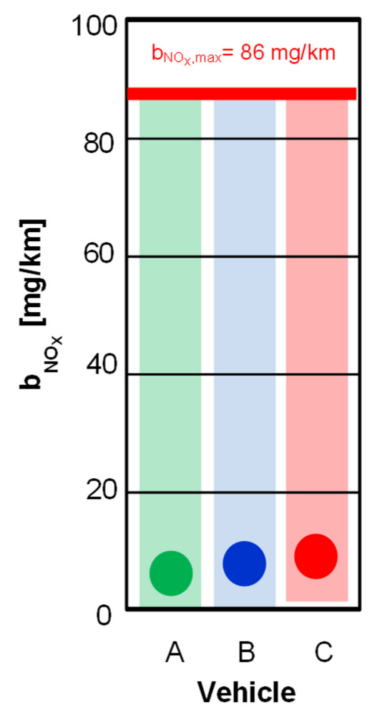

(c)

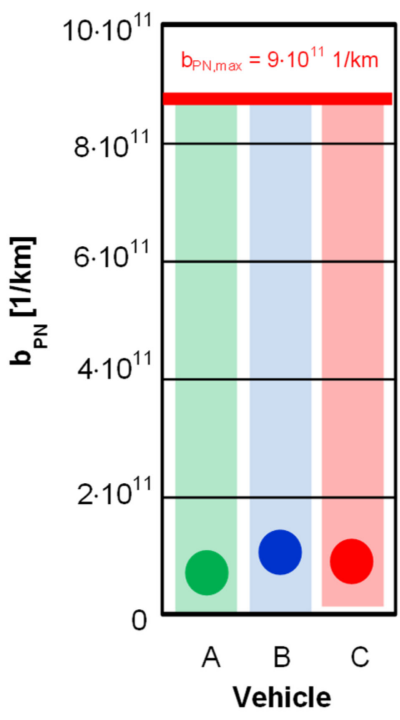

(d)

Figure 9. Value of the minimum road emission of carbon dioxide (a), carbon monoxide (b), nitrogen oxides (c), and particle number (d) obtained according to the algorithm for variable exhaust emission intensity; data provided in Tables A5-A7.

\subsection{Plug-in Vehicles Emission Category}

The environmental assessment of the vehicles was initiated upon the analysis of the obtained results of actual road emissions of individual exhaust components (p. 4) and upon adopting the maximum values (values adopted based on the emission standards- $\mathrm{p}$. 5.1.1) and the minimum ones (values adopted based on the theoretical determination of the minimum for the measured emission intensity- $-\mathrm{p}$. 5.1.2). The environmental categorization (EC - ecological category) for each exhaust component was performed based on the determination of the percentage value of the obtained road emission depending on the minimum and maximum value according to the formula:

$$
\mathrm{EC}_{\mathrm{j}}[\%]=100 \% \times\left(\mathrm{b}_{\mathrm{j}}-\mathrm{b}_{\mathrm{j}, \min }\right) /\left(\mathrm{b}_{\mathrm{j}, \max }-\mathrm{b}_{\mathrm{j}, \mathrm{min}}\right) .
$$

Equation (10) describes the process of scaling that adapts the value of any exhaust component to the new limits determined with the minimum $(0 \%)$ and the maximum value $(100 \%)$. Such an approach enables each road emission to be presented as a value ranging from $0-100 \%$, as shown in Table 9 . According to the results presented below, one can confirm that the highest values $(\mathrm{EC}=64-68 \%)$ are gained for the road emission of carbon dioxide, which indicates great potential for improvement in this matter. In the case of the emission category pertaining to the road emission of carbon monoxide, the determined values are in the range from $4 \%$ to $11 \%$. This confirms a substantial reserve of approximately $90 \%$, which is tantamount with the fact that the analyzed vehicles generate much less of this exhaust component compared to the emission standard prescribed for the RDE test. We have a similar situation for the road emission of nitrogen oxides and particle number: the obtained values from $4-7 \%$ also confirm the rule. 
Table 9. Real values of the road exhaust emissions $\left(b_{j}\right)$, theoretically determined maximum value $\left(b_{j, \max }\right)$ minimum value $\left(b_{j, \min }\right)$, and the environmental assessment $\left(E C_{j}\right)$ for individual plug-in hybrid vehicles.

\begin{tabular}{cccc}
\hline Parameter & Vehicle A & Vehicle B & Vehicle C \\
\hline $\mathrm{b}_{\mathrm{CO} 2}[\mathrm{~g} / \mathrm{km}]$ & 65 & 61 & 64 \\
$\mathrm{~b}_{\mathrm{CO}}[\mathrm{mg} / \mathrm{km}]$ & 110 & 81 & 53 \\
$\mathrm{~b}_{\mathrm{NOx}}[\mathrm{mg} / \mathrm{km}]$ & 3.3 & 5.9 & 8 \\
$\mathrm{~b}_{\mathrm{PN}}[1 / \mathrm{km}]$ & $6.90 \cdot 10^{10}$ & $8.30 \cdot 10^{10}$ & $3.10 \cdot 10^{10}$ \\
\hline $\mathrm{b}_{\mathrm{CO} 2, \max }[\mathrm{g} / \mathrm{km}]$ & 95 & 95 & 95 \\
$\mathrm{~b}_{\mathrm{CO}, \max }[\mathrm{mg} / \mathrm{km}]$ & 1000 & 1000 & 1000 \\
$\mathrm{~b}_{\mathrm{NOx}, \max }[\mathrm{mg} / \mathrm{km}]$ & 86 & 86 & 86 \\
$\mathrm{~b}_{\mathrm{PN}, \max }[1 / \mathrm{km}]$ & $9.00 \cdot 10^{11}$ & $9.00 \cdot 10^{11}$ & $9.00 \cdot 10^{11}$ \\
\hline $\mathrm{b}_{\mathrm{CO} 2, \min }[\mathrm{g} / \mathrm{km}]$ & 0 & 0 & 5.99 \\
$\mathrm{~b}_{\mathrm{CO}, \min }[\mathrm{mg} / \mathrm{km}]$ & 0 & 0 & 11.43 \\
$\mathrm{~b}_{\mathrm{NOx}, \min }[\mathrm{mg} / \mathrm{km}]$ & 0 & 0 & 2.35 \\
$\mathrm{~b}_{\mathrm{PN}, \min }[1 / \mathrm{km}]$ & 0 & 0 & $2.00 \cdot 10^{9}$ \\
\hline $\mathrm{EC}_{\mathrm{CO} 2}$ & $68 \%$ & $64 \%$ & $65 \%$ \\
$\mathrm{EC}_{\mathrm{CO}}$ & $11 \%$ & $8 \%$ & $4 \%$ \\
$\mathrm{EC}_{\mathrm{NOx}}$ & $4 \%$ & $7 \%$ & $7 \%$ \\
$\mathrm{EC}_{\mathrm{PN}}$ & $8 \%$ & $9 \%$ & $3 \%$ \\
\hline
\end{tabular}

The values of emissions of individual exhaust components for individual vehicles were used for the overall environmental assessment of the analyzed vehicles. An arithmetic average relation was applied, yet the authors are aware that a valuation can be introduced in terms of the significance of each of the exhaust components. Such an action would require considering the hazard of individual exhaust components to human health and the criteria of its assessment would require further analyses. Therefore, the application of an arithmetic average allows all the discussed exhaust components to be treated equally. The obtained values, shown in Figure 10, show that all the vehicles under analysis obtain ecological values lower than 50\%, which classifies them to the ecological category A.

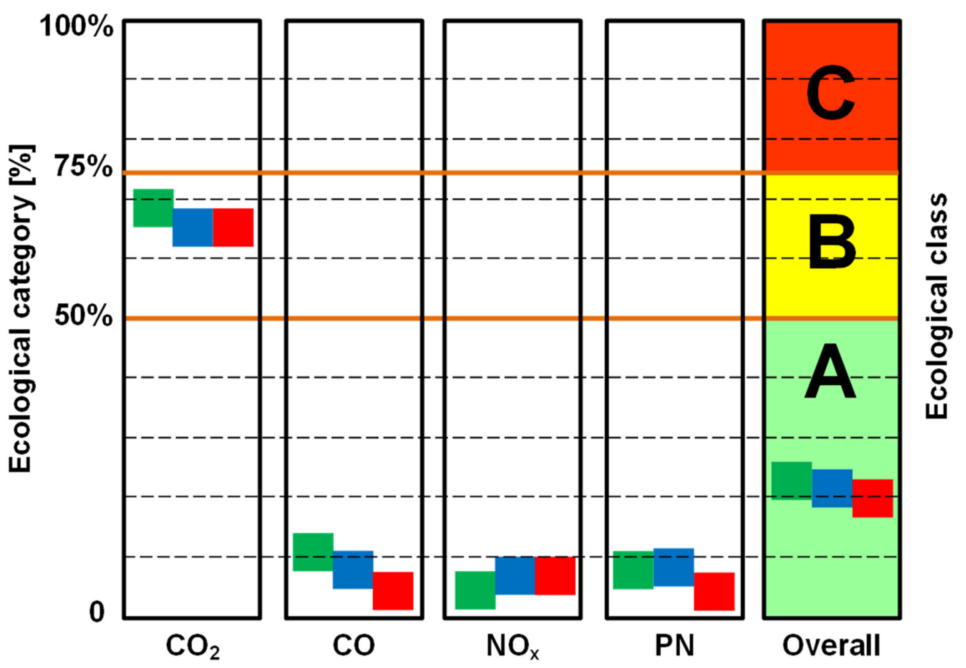

Figure 10. Value of the minimum road emission in the RDE test ( $\square$-vehicle A, $\square$-vehicle B, $\square$ vehicle $\mathrm{C}$ ) obtained according to the algorithm for variable exhaust emission intensity; data provided in Tables A4-A6.

An explanation is required for the case in which the road emission of an exhaust component is greater than the product of the CF coefficient and the value provided in the emission standard. In such a case, the value of CF will be greater than $100 \%$, which, for 
conventional vehicles, will result in the necessity to extend the range of qualification and emission categories.

\section{Conclusions}

In the paper, the authors presented the process of creation of a new tool that can be used in the environmental assessment of motor vehicles under actual traffic conditions. Currently, the certificate of type approval provides the final results as regards the compliance with the vehicle ecological category, yet without the emission-related valuation of the vehicle. The methodology presented in the paper and applied when investigating plug-in hybrid vehicles unveils its practical application, which is confirmation that the analyzed vehicles adapt well environmentally when it comes to the trends in electromobility, given their emission category (A). The division into emission categories of plug-in hybrid vehicles can be introduced in a different subjective way, e.g., by creating more categories from A to E.

The major conclusions of the paper can be summarized in the following points:

1. The concept of this paper was aimed at indicating the methodology of processing of the hybrid vehicles exhaust emission results, but it could also be of use for either conventional vehicles or electric ones, in which instead of analyzing the exhaust emissions one could focus on the energy consumption. The authors see no contraindications to applying the methodology in heavy-duty vehicles, in the case of which other indexes are used for the description of their emissions-related performance (referred to the performed work of a vehicle).

2. The estimated minimum exhaust emission results for the RDE test assuming constant emission rates are about $20-40 \%$ less than the actual values. However, estimating the minimum values, for variable emission rates, reveals the largest differences, as the minimum values can be zero. This is a characteristic feature of hybrid vehicles, especially PHEVs, whereby using a large electric capacity of the battery, zero emissions can be achieved in the RDE test. Therefore, the next stage of the research should be a parallel analysis consisting in the evaluation of emission aspects on the one hand, and energy consumption aspects on the other.

3. In the era of fighting for environmental protection, the additional emission class indicator of a vehicle may be an important aspect in the consumer's choice of a vehicle. Due to the campaigns of the European Union and member states, consumer awareness of the harmfulness of exhaust emissions is constantly rising. The proposed method of categorizing hybrid vehicles (the authors plan to extend the RDE study and publish an article on the energy consumption of vehicles in the future) is clear and transparent, which may support the choice of greater ecological power unit.

4. The research presented in this paper describes an alternative way to evaluate the environmental performance of vehicles, although limiting oneself only to emissions for PHEVs is not a closed solution. The next stage of work will be to develop a methodology for evaluating the energy consumption of hybrid and electric vehicles in road tests. The result of such a procedure will be the ecological evaluation of vehicles powered only by combustion engines (evaluation on the basis of exhaust emissions), hybrid vehicles-HEVs and PHEVs (evaluation on the basis of exhaust emissions and energy consumption), and vehicles powered by electricity or fuel cells (evaluation on the basis of energy consumption).

Author Contributions: Conceptualization, K.S. and J.P.; methodology, K.S. and J.P.; software, K.S.; validation, K.S. and J.P.; formal analysis, K.S; investigation, K.S. and J.P.; resources, K.S. and J.P.; data curation, K.S. and J.P.; writing—original draft preparation, K.S.; writing—review and editing, K.S. and J.P.; visualization, K.S. and J.P.; supervision, K.S. and J.P.; project administration, J.P.; funding acquisition, K.S. and J.P. All authors have read and agreed to the published version of the manuscript.

Funding: This research was funded by Poznan University of Technology, grant number 0415/SBAD/0319.

Institutional Review Board Statement: Not Applicable. 
Informed Consent Statement: Not Applicable.

Data Availability Statement: The data presented in this study are available on request from the corresponding author.

Conflicts of Interest: The authors declare no conflict of interest.

\section{Abbreviations}

a acceleration vehicle

b road exhaust emission

CF Conformity Factor

$\mathrm{CoV}$ coefficient of variation

E exhaust emission rate

EC ecological category

EV Electric Vehicle

FID flame ionization detector

GNG Generalized Reduced Gradient

$\mathrm{h} \quad$ driving test altitude

HEV Hybrid Electric Vehicle

M motorway

MAV Moving Average Windows

NDIR non-dispersive infrared

NDUV non-dispersive ultra violet

NEDC New European Driving Cycle

PEMS Portable Emission Measurement System

PHEV Plug-in Hybrid Electric Vehicle

$\mathrm{R}$ rural

RDE Real Driving Emissions

RPA Relative Positive Acceleration

$\mathrm{S}$ distance

$t$ time

u share

U urban

V vehicle speed

WLTC Worldwide-harmonized Light duty vehicles Test Cycle

WLTP Worldwide-harmonized Light duty vehicles Test Procedure

\section{Appendix A}

Table A1. Characteristic data of the performed tests and their comparison with the admissible values.

\begin{tabular}{cccccc}
\hline Trip Characteristics & Vehicle A & Vehicle B & Vehicle C & Valid & Unit \\
\hline Distance & 91.90 & 97.40 & 96.45 & - & $\mathrm{km}$ \\
Duration & 106.17 & 104.52 & 107.83 & $90-120$ & $\mathrm{~min}$ \\
Cold start duration & 5.00 & 5.00 & 5.00 & 5.00 & $\mathrm{~min}$ \\
Urban distance & 33.73 & 32.22 & 32.88 & $>16$ & $\mathrm{~km}$ \\
Rural distance & 25.25 & 30.79 & 31.58 & $>16$ & $\mathrm{~km}$ \\
Motorway distance & 32.92 & 34.39 & 31.98 & $>16$ & $\mathrm{~km}$ \\
Urban distance share & 36.70 & 33.08 & 34.10 & $29-44$ & $\%$ \\
Rural distance share & 27.48 & 31.61 & 32.74 & $23-43$ & $\%$ \\
Motorway distance share & 35.82 & 35.31 & 33.16 & $23-43$ & $\%$ \\
Urban average speed & 30.05 & 31.14 & 30.33 & $15-40$ & $\mathrm{~km} / \mathrm{h}$ \\
Rural average speed & 74.09 & 76.23 & 75.34 & - & $\mathrm{km} / \mathrm{h}$ \\
Motorway average speed & 107.55 & 113.37 & 108.83 & - & $\mathrm{km} / \mathrm{h}$ \\
Total trip average speed & 51.94 & 55.91 & 53.66 & - & $\mathrm{km} / \mathrm{h}$ \\
Motorway speed above & 0.00 & 0.00 & 0.00 & $<3 \% \mathrm{mot}$. & $\%$ \\
145 km/h & & & & time & $\%$ \\
\hline
\end{tabular}


Table A1. Cont.

\begin{tabular}{cccccc}
\hline Trip Characteristics & Vehicle A & Vehicle B & Vehicle C & Valid & Unit \\
\hline Motorway speed above & 16.28 & 16.63 & 17.32 & $\geq 5$ & $\mathrm{~min}$ \\
100 km/h & 20.09 & 17.91 & 15.12 & $6-30$ & $\%$ \\
Stop share (Urban phase) & 0.00 & 0.00 & 0.00 & $\leq 15$ & $\mathrm{~s}$ \\
Initial idling duration & 23.70 & 23.68 & 21.33 & $15-40$ & $\mathrm{~km} / \mathrm{h}$ \\
Cold start average speed & 44.25 & 45.86 & 47.00 & $<60$ & $\mathrm{~km} / \mathrm{h}$ \\
Cold start maximum & 0.00 & 31.00 & 18.00 & $\leq 90$ & $\mathrm{~s}$ \\
$\quad$ speed & & & &
\end{tabular}

Table A2. Road emissions for the RDE test (assuming constant exhaust emission intensity) —output data obtained from the algorithm and the proposed values for the generalized test (Vehicle A).

\begin{tabular}{|c|c|c|c|c|c|c|c|c|c|c|}
\hline \multirow{2}{*}{$\begin{array}{c}\text { Exhaust } \\
\text { Components }\end{array}$} & \multicolumn{3}{|c|}{$\mathbf{t}$} & \multicolumn{3}{|c|}{$S$} & \multicolumn{3}{|c|}{$\mathbf{U}$} & \multirow{2}{*}{$\frac{\mathrm{b}}{\mathrm{RDE}}$} \\
\hline & $\begin{array}{c}\mathrm{U} \\
{[\mathrm{s}]}\end{array}$ & $\begin{array}{c}\mathbf{R} \\
{[\mathrm{s}]}\end{array}$ & $\begin{array}{l}\mathbf{M} \\
{[\mathrm{s}]}\end{array}$ & $\begin{array}{c}\mathrm{U} \\
{[\mathrm{km}]}\end{array}$ & $\begin{array}{c}\mathbf{R} \\
{[\mathrm{km}]}\end{array}$ & $\begin{array}{c}\mathbf{M} \\
{[\mathrm{km}]}\end{array}$ & $\begin{array}{c}\mathbf{U} \\
{[-]}\end{array}$ & $\begin{array}{c}\mathbf{R} \\
{[-]}\end{array}$ & $\begin{array}{l}\mathbf{M} \\
{[-]}\end{array}$ & \\
\hline $\mathrm{CO}_{2}$ & 4157 & 640 & 603 & 19.1 & 16.0 & 24.3 & 0.321 & 0.270 & 0.409 & $49.4 \mathrm{~g} / \mathrm{km}$ \\
\hline $\mathrm{CO}$ & 3999 & 717 & 684 & 18.6 & 17.9 & 27.5 & 0.290 & 0.280 & 0.430 & $83.4 \mathrm{mg} / \mathrm{km}$ \\
\hline $\mathrm{NO}_{\mathrm{x}}$ & 4106 & 640 & 654 & 18.9 & 16.0 & 26.3 & 0.309 & 0.261 & 0.430 & $2.51 \mathrm{mg} / \mathrm{km}$ \\
\hline $\mathrm{PN}$ & 3999 & 718 & 683 & 18.6 & 18.0 & 27.5 & 0.290 & 0.280 & 0.430 & $5.2 \cdot 10^{10} 1 / \mathrm{km}$ \\
\hline Average & 4065 & 679 & 656 & 18.8 & 17.0 & 26.4 & 0.303 & 0.273 & 0.425 & - \\
\hline St. deviation & 68.8 & 38.8 & 33.0 & 0.21 & 0.97 & 1.33 & 0.01 & 0.01 & 0.01 & - \\
\hline $\mathrm{CoV}[\%]$ & $1.7 \%$ & $5.7 \%$ & $5.0 \%$ & $1.1 \%$ & $5.7 \%$ & $5.0 \%$ & $4.4 \%$ & $2.9 \%$ & $2.1 \%$ & - \\
\hline
\end{tabular}

Table A3. Road emissions for the RDE test (assuming constant exhaust emission intensity)—output data obtained from the algorithm and the proposed values for the generalized test (Vehicle B).

\begin{tabular}{|c|c|c|c|c|c|c|c|c|c|c|}
\hline \multirow{2}{*}{$\begin{array}{c}\text { Exhaust } \\
\text { Components }\end{array}$} & \multicolumn{3}{|c|}{$\mathbf{t}$} & \multicolumn{3}{|c|}{$\mathbf{S}$} & \multicolumn{3}{|c|}{$\mathbf{U}$} & \multirow{2}{*}{$\frac{\mathrm{b}}{\mathrm{RDE}}$} \\
\hline & $\begin{array}{c}\mathrm{U} \\
{[\mathrm{s}]}\end{array}$ & $\begin{array}{c}R \\
{[s]}\end{array}$ & $\begin{array}{l}\mathbf{M} \\
{[\mathrm{s}]}\end{array}$ & $\begin{array}{c}\mathrm{U} \\
{[\mathrm{km}]}\end{array}$ & $\begin{array}{c}R \\
{[\mathrm{~km}]}\end{array}$ & $\begin{array}{c}\mathbf{M} \\
{[\mathbf{k m}]}\end{array}$ & $\begin{array}{c}\mathrm{U} \\
{[-]}\end{array}$ & $\begin{array}{c}\mathbf{R} \\
{[-]}\end{array}$ & $\begin{array}{l}\mathbf{M} \\
{[-]}\end{array}$ & \\
\hline $\mathrm{CO}_{2}$ & 4096 & 878 & 427 & 16.0 & 21.9 & 17.2 & 0.290 & 0.398 & 0.312 & $48.4 \mathrm{~g} / \mathrm{km}$ \\
\hline $\mathrm{CO}$ & 4013 & 710 & 677 & 18.4 & 17.8 & 27.2 & 0.290 & 0.280 & 0.430 & $65.2 \mathrm{mg} / \mathrm{km}$ \\
\hline $\mathrm{NO}_{\mathrm{x}}$ & 4004 & 715 & 681 & 18.5 & 17.9 & 27.4 & 0.290 & 0.280 & 0.430 & $4.68 \mathrm{mg} / \mathrm{km}$ \\
\hline $\mathrm{PN}$ & 4040 & 640 & 720 & 22.4 & 16.0 & 29.0 & 0.333 & 0.237 & 0.430 & $6.6 \cdot 10^{10} 1 / \mathrm{km}$ \\
\hline Average & 4038 & 736 & 626 & 18.8 & 18.4 & 25.2 & 0.301 & 0.299 & 0.400 & - \\
\hline St. deviation & 35.8 & 87.2 & 116.4 & 2.31 & 2.18 & 4.69 & 0.02 & 0.06 & 0.05 & - \\
\hline $\mathrm{CoV}[\%]$ & $0.9 \%$ & $11.8 \%$ & $18.6 \%$ & $12.3 \%$ & $11.8 \%$ & $18.6 \%$ & $6.1 \%$ & $20.0 \%$ & $12.8 \%$ & - \\
\hline
\end{tabular}

Table A4. Road emissions for the RDE test (assuming constant exhaust emission intensity)—output data obtained from the algorithm and the proposed values for the generalized test (Vehicle C).

\begin{tabular}{|c|c|c|c|c|c|c|c|c|c|c|}
\hline \multirow{2}{*}{$\begin{array}{c}\text { Exhaust } \\
\text { Components }\end{array}$} & \multicolumn{3}{|c|}{$\mathbf{t}$} & \multicolumn{3}{|c|}{$\mathbf{S}$} & \multicolumn{3}{|c|}{$\mathbf{U}$} & \multirow{2}{*}{$\frac{\mathrm{b}}{\mathrm{RDE}}$} \\
\hline & $\begin{array}{c}\mathrm{U} \\
{[\mathrm{s}]}\end{array}$ & $\begin{array}{l}\mathbf{R} \\
{[\mathrm{s}]}\end{array}$ & $\begin{array}{l}\mathbf{M} \\
{[\mathbf{s}]}\end{array}$ & $\begin{array}{c}\mathrm{U} \\
{[\mathrm{km}]}\end{array}$ & $\begin{array}{c}\mathbf{R} \\
{[\mathrm{km}]}\end{array}$ & $\begin{array}{c}\mathbf{M} \\
{[\mathrm{km}]}\end{array}$ & $\begin{array}{l}\mathbf{U} \\
{[-]}\end{array}$ & $\begin{array}{c}\mathbf{R} \\
{[-]}\end{array}$ & $\begin{array}{l}\mathbf{M} \\
{[-]}\end{array}$ & \\
\hline $\mathrm{CO}_{2}$ & 3673 & 915 & 812 & 22.7 & 22.9 & 32.7 & 0.290 & 0.292 & 0.418 & $49.3 \mathrm{~g} / \mathrm{km}$ \\
\hline $\mathrm{CO}$ & 4015 & 709 & 676 & 18.4 & 17.7 & 27.2 & 0.290 & 0.280 & 0.430 & $41.4 \mathrm{mg} / \mathrm{km}$ \\
\hline $\mathrm{NO}_{\mathrm{x}}$ & 4002 & 716 & 682 & 18.5 & 17.9 & 27.5 & 0.290 & 0.280 & 0.430 & $6.2 \mathrm{mg} / \mathrm{km}$ \\
\hline $\mathrm{PN}$ & 3811 & 911 & 678 & 20.5 & 22.8 & 27.3 & 0.290 & 0.323 & 0.387 & $2.4 \cdot 10^{10} 1 / \mathrm{km}$ \\
\hline Average & 3875 & 813 & 712 & 20.0 & 20.3 & 28.7 & 0.290 & 0.294 & 0.416 & - \\
\hline St. deviation & 142 & 101 & 58 & 1.75 & 2.51 & 2.32 & 0.00 & 0.02 & 0.02 & - \\
\hline $\operatorname{CoV}[\%]$ & $3.7 \%$ & $12.4 \%$ & $8.1 \%$ & $8.7 \%$ & $12.4 \%$ & $8.1 \%$ & $0.0 \%$ & $6.0 \%$ & $4.2 \%$ & - \\
\hline
\end{tabular}


Table A5. Road emissions for the RDE test (assuming variable exhaust emission intensity) — output data obtained from the algorithm and the proposed values for the generalized test (Vehicle A).

\begin{tabular}{|c|c|c|c|c|c|c|c|c|c|c|}
\hline \multirow{2}{*}{$\begin{array}{c}\text { Exhaust } \\
\text { Components }\end{array}$} & \multicolumn{3}{|c|}{$\mathbf{t}$} & \multicolumn{3}{|c|}{$\mathbf{S}$} & \multicolumn{3}{|c|}{$\mathbf{U}$} & \multirow{2}{*}{$\begin{array}{c}\mathrm{b} \\
\mathrm{RDE}\end{array}$} \\
\hline & $\begin{array}{c}\mathrm{U} \\
{[\mathrm{s}]}\end{array}$ & $\begin{array}{c}R \\
{[s]}\end{array}$ & $\begin{array}{l}\text { M } \\
{[s]}\end{array}$ & $\begin{array}{c}\mathrm{U} \\
{[\mathrm{km}]}\end{array}$ & $\begin{array}{c}\mathbf{R} \\
{[\mathrm{km}]}\end{array}$ & $\begin{array}{c}\mathbf{M} \\
{[\mathrm{km}]}\end{array}$ & $\begin{array}{l}\mathbf{U} \\
{[-]}\end{array}$ & $\begin{array}{c}\mathbf{R} \\
{[-]}\end{array}$ & $\begin{array}{l}\mathbf{M} \\
{[-]}\end{array}$ & \\
\hline $\mathrm{CO}_{2}$ & 3665 & 1338 & 397 & 16.0 & 16.0 & 16.0 & 0.333 & 0.333 & 0.333 & 0 \\
\hline $\mathrm{CO}$ & 3665 & 1338 & 397 & 16.0 & 16.0 & 16.0 & 0.333 & 0.333 & 0.333 & 0 \\
\hline $\mathrm{NO}_{\mathrm{x}}$ & 3665 & 1338 & 397 & 16.0 & 16.0 & 16.0 & 0.333 & 0.333 & 0.333 & 0 \\
\hline $\mathrm{PN}$ & 3665 & 1338 & 397 & 16.0 & 16.0 & 16.0 & 0.333 & 0.333 & 0.333 & 0 \\
\hline Average & 3665 & 1338 & 397 & 16.00 & 16.00 & 16.00 & 0.333 & 0.333 & 0.333 & - \\
\hline St. deviation & 0.00 & 0.00 & 0.00 & 0.00 & 0.00 & 0.00 & 0.00 & 0.00 & 0.00 & - \\
\hline $\mathrm{CoV}[\%]$ & $0.0 \%$ & $0.0 \%$ & $0.0 \%$ & $0.0 \%$ & $0.0 \%$ & $0.0 \%$ & $0.0 \%$ & $0.0 \%$ & $0.0 \%$ & - \\
\hline
\end{tabular}

Table A6. Road emissions for the RDE test (assuming variable exhaust emission intensity)—output data obtained from the algorithm and the proposed values for the generalized test (Vehicle B).

\begin{tabular}{|c|c|c|c|c|c|c|c|c|c|c|}
\hline \multirow{2}{*}{$\begin{array}{c}\text { Exhaust } \\
\text { Components }\end{array}$} & \multicolumn{3}{|c|}{$\mathbf{t}$} & \multicolumn{3}{|c|}{$S$} & \multicolumn{3}{|c|}{$\mathbf{U}$} & \multirow{2}{*}{$\frac{\mathrm{b}}{\mathrm{RDE}}$} \\
\hline & $\begin{array}{l}\mathrm{U} \\
{[\mathrm{s}]}\end{array}$ & $\begin{array}{c}R \\
{[s]}\end{array}$ & $\begin{array}{l}\mathbf{M} \\
{[\mathrm{s}]}\end{array}$ & $\begin{array}{c}\mathrm{U} \\
{[\mathrm{km}]}\end{array}$ & $\begin{array}{c}R \\
{[\mathbf{k m}]}\end{array}$ & $\begin{array}{c}\text { M } \\
{[\mathrm{km}]}\end{array}$ & $\begin{array}{c}\mathbf{U} \\
{[-]}\end{array}$ & $\begin{array}{c}\mathbf{R} \\
{[-]}\end{array}$ & $\begin{array}{l}\mathbf{M} \\
{[-]}\end{array}$ & \\
\hline $\mathrm{CO}_{2}$ & 3602 & 1338 & 460 & 16.0 & 16.0 & 18.5 & 0.317 & 0.317 & 0.367 & 0 \\
\hline $\mathrm{CO}$ & 3602 & 1338 & 460 & 16.0 & 16.0 & 18.5 & 0.317 & 0.317 & 0.367 & 0 \\
\hline $\mathrm{NO}_{\mathrm{x}}$ & 3602 & 1338 & 460 & 16.0 & 16.0 & 18.5 & 0.317 & 0.317 & 0.367 & 0 \\
\hline $\mathrm{PN}$ & 3602 & 1338 & 460 & 16.0 & 16.0 & 18.5 & 0.317 & 0.317 & 0.367 & 0 \\
\hline Average & 3602 & 1338 & 460 & 16.0 & 16.0 & 18.5 & 0.317 & 0.317 & 0.367 & - \\
\hline St. deviation & 0.0 & 0.0 & 0.0 & 0.00 & 0.00 & 0.00 & 0.00 & 0.00 & 0.00 & - \\
\hline CoV [\%] & $0.0 \%$ & $0.0 \%$ & $0.0 \%$ & $0.0 \%$ & $0.0 \%$ & $0.0 \%$ & $0.0 \%$ & $0.0 \%$ & $0.0 \%$ & - \\
\hline
\end{tabular}

Table A7. Road emissions for the RDE test (assuming variable exhaust emission intensity) — output data obtained from the algorithm and the proposed values for the generalized test (Vehicle C).

\begin{tabular}{|c|c|c|c|c|c|c|c|c|c|c|}
\hline \multirow{2}{*}{$\begin{array}{c}\text { Exhaust } \\
\text { Components }\end{array}$} & \multicolumn{3}{|c|}{$\mathbf{t}$} & \multicolumn{3}{|c|}{$S$} & \multicolumn{3}{|c|}{$\mathbf{U}$} & \multirow{2}{*}{$\frac{\mathrm{b}}{\mathrm{RDE}}$} \\
\hline & $\begin{array}{c}\mathrm{U} \\
{[\mathrm{s}]}\end{array}$ & $\begin{array}{c}\mathrm{R} \\
\text { [s] }\end{array}$ & $\begin{array}{l}\mathbf{M} \\
\text { [s] }\end{array}$ & $\underset{[\mathrm{km}]}{\mathrm{U}}$ & $\underset{[\mathrm{km}]}{\mathrm{R}}$ & $\begin{array}{c}\mathbf{M} \\
{[\mathbf{k m}]}\end{array}$ & $\underset{[-]}{\mathbf{U}}$ & $\begin{array}{c}\mathbf{R} \\
{[-]}\end{array}$ & $\begin{array}{l}\mathbf{M} \\
{[-]}\end{array}$ & \\
\hline $\mathrm{CO}_{2}$ & 3665 & 1338 & 397 & 16.0 & 16.0 & 16.0 & 0.333 & 0.333 & 0.333 & $6.0 \mathrm{~g} / \mathrm{km}$ \\
\hline $\mathrm{CO}$ & 3665 & 1338 & 397 & 16.0 & 16.0 & 16.0 & 0.333 & 0.333 & 0.333 & $11.4 \mathrm{mg} / \mathrm{km}$ \\
\hline $\mathrm{NO}_{\mathrm{x}}$ & 3665 & 1338 & 397 & 16.0 & 16.0 & 16.0 & 0.333 & 0.333 & 0.333 & $2.3 \mathrm{mg} / \mathrm{km}$ \\
\hline $\mathrm{PN}$ & 3665 & 1338 & 397 & 16.0 & 16.0 & 16.0 & 0.333 & 0.333 & 0.333 & $2.0 \cdot 10^{9} 1 / \mathrm{km}$ \\
\hline Average & 3665 & 1338 & 397 & 16.0 & 16.0 & 16.0 & 0.333 & 0.333 & 0.333 & - \\
\hline St. deviation & 0 & 0 & 0 & 0.00 & 0.00 & 0.00 & 0.00 & 0.00 & 0.00 & - \\
\hline CoV [\%] & $0.0 \%$ & $0.0 \%$ & $0.0 \%$ & $0.0 \%$ & $0.0 \%$ & $0.0 \%$ & $0.0 \%$ & $0.0 \%$ & $0.0 \%$ & - \\
\hline
\end{tabular}

\section{References}

1. The European Parliament and The Council of The European Union. Commission Regulation (EC) $715 / 2007$ of the European Parliament and of the Council of 20 June 2007 on Type Approval of Motor Vehicles with Respect to Emissions from Light Passenger and Commercial Vehicles (Euro 5 and Euro 6) and on Access to Vehicle Repair and Maintenance Information. Off. J. Eur. Union 2007, L 171, 1-16.

2. The Commission of the European Communities. Commission Regulation (EC) 692/2008 of 18 July 2008 Implementing and Amending Regulation (EC) 715/2007 of the European Parliament and of the Council on Type-Approval of Motor Vehicles with Respect to Emissions from Light Passenger and Commercial Vehicles (Euro 5 and Euro 6) and on Access to Vehicle Repair and Maintenance Information, European Commission (EC). Off. J. Eur. Union 2008, L 199, 1-136.

3. The European Commission. Commission Regulation (EU) 2016/427 of 10 March 2016 Amending Regulation (EC) No. $692 / 2008$ as Regards Emissions from Light Passenger and Commercial Vehicles (Euro 6), Verifying Real Driving Emissions. Off. J. Eur. Union 2016, L 82, 1-98. 
4. The European Commission. Commission Regulation (EU) 2016/646 of 20 April 2016 Amending Regulation (EC) No. 692/2008 as Regards Emissions from Light Passenger and Commercial Vehicles (Euro 6), Verifying Real Driving Emissions. Off. J. Eur. Union 2016, L 109, 1-22.

5. Commission Regulation (EU) 2017/1151 of 1 June 2017 Supplementing Regulation (EC) No 715/2007 of the European Parliament and of the Council on Type-Approval of Motor Vehicles with Respect to Emissions from Light Passenger and Commercial Vehicles (Euro 5 and Euro 6) and on Access to Vehicle Repair and Maintenance Information, Amending Directive 2007/46/EC of the European Parliament and of the Council, Commission Regulation (EC) No 692/2008 and Commission Regulation (EU) No 1230/2012 and Repealing Commission Regulation (EC) No 692/2008. Off. J. Eur. Union L 175. 2017, pp. 1-643. Available online: http:/ / data.europa.eu/eli/reg/2017/1151/oj (accessed on 22 December 2020).

6. The European Commission. Commission Regulation (EU) 2017/1154 of 7 June 2017 Amending Regulation (EU) 2017/1151 Supplementing Regulation (EC) No 715/2007 of the European Parliament and of the Council on Type-Approval of Motor Vehicles with Respect to Emissions from Light Passenger and Commercial Vehicles (Euro 5 and Euro 6) and on Access to Vehicle Repair and Maintenance Information, Amending Directive 2007/46/EC of the European Parliament and of the Council, Commission Regulation (EC) No 692/2008 and Commission Regulation (EU) No 1230/2012 and Repealing Regulation (EC) No 692/2008 and Directive 2007/46/EC of the European Parliament and of the Council as Regards Real-Driving Emissions from Light Passenger and Commercial Vehicles (Euro 6). Off. J. Eur. Union 2017, L 175, 708-732.

7. Pielecha, J.; Andrych-Zalewska, M.; Skobiej, K. The impact of using an in-cylinder catalyst on the exhaust gas emission in real driving conditions tests of a Diesel engine. IOP Conf. Ser. Mater. Sci. Eng. 2018, 421, 042064. [CrossRef]

8. Pielecha, J.; Skobiej, K. Evaluation of ecological extremes of vehicles in road emission tests. Arch. Transp. 2020, 4, 33-46. [CrossRef]

9. Katrašnik, T. Hybridization of powertrain and downsizing of IC engine-A way to reduce fuel consumption and pollutant emissions-Part 1. Energy Convers. Manag. 2007, 48, 1411-1423. [CrossRef]

10. Wirasingha, S.G.; Schofield, N.; Emadi, A. Plug-in hybrid electric vehicle developments in the US: Trends, barriers, and economic feasibility. In Proceedings of the IEEE Vehicle Power Propulsion Conference, Harbin, China, 3-5 September 2008. [CrossRef]

11. Khan, M.; Kockelma, K.M. Predicting the market potential of plug-in electric vehicles using multiday GPS data. Energy Policy 2012, 46, 225-233. [CrossRef]

12. Cieslik, W.; Szwajca, F.; Golimowski, W.; Berger, A. Experimental analysis of residential photovoltanic (PV) and battery electric vehicle (BEV) systems in terms of annual energy utilization. Energies 2021, 14, 1085. [CrossRef]

13. Yi, Z.; Bauer, P.H. Effects of environmental factors on electric vehicle energy consumption: A sensitivity analysis. IET Electr. Syst. Transp. 2017, 7, 3-13. [CrossRef]

14. Li, G.; Zhang, X.P. Modeling of plug-in hybrid electric vehicle charging demand in probabilistic power flow calculations. IEEE Trans. Smart Grid 2012, 3, 492-499. [CrossRef]

15. Pielecha, J.; Skobiej, K.; Kurtyka, K. Exhaust emissions and energy consumption analysis of conventional, hybrid, and electric vehicles in real driving cycles. Energies 2020, 13, 6423. [CrossRef]

16. IEA. Global EV Outlook 2020. 2020. Available online: https://www.iea.org/reports/global-ev-outlook-2020 (accessed on 21 October 2020).

17. Lang, M. Initial GVI Roadmap, Österreichischer Automobil Motorrad und Touring Club (ÖAMTC), GVI—Green Vehicle Index, Horizon 2020, Grant Agreement ID: 814794. 2019. Available online: https://www.gvi-project.eu/wp-content/uploads/sites/2/ D4.1-Roadmap.pdf (accessed on 22 March 2021).

18. Kapus, P. Passenger Car Powertrain 4.x-Fuel Consumption, Emissions and Cost, Webinar, AVL List GmbH. 2020. Available online: https: / / www.avl.com/- / passenger-car-powertrain-4.x-fuel-consumption-emissions-and-cost (accessed on 2 June 2020).

19. Korn, T. The most effective technology to comply with $\mathrm{CO}_{2}$-legislation: The new generation of hydrogen internal combustion engines. In Proceedings of the International Vienna Motor Symposium, Vienna, Austria, 22-24 April 2020.

20. Lasdon, L.S.; Waren, A.D.; Jain, A.; Ratner, M. Design and testing of a generalized reduced gradient code for nonlinear programming. ACM Trans. Math. Softw. 1978, 4, 34-50. [CrossRef] 